\title{
Indigenous medicinal plants of Pakistan used to treat skin diseases: a review
}

\author{
Alamgeer ${ }^{1 *}$, Amber Sharif ${ }^{1}$, Hira Asif ${ }^{1}$, Waqas Younis ${ }^{1}$, Humayun Riaz $^{2}$, Ishfaq Ali Bukhari ${ }^{3}$ \\ and Asaad Mohamed Assiri ${ }^{4}$
}

\begin{abstract}
Ethno-pharmacological relevance: Plants are providing reliable therapy since time immemorial. Pakistan has a great diversity in medicinal flora and people use these ethno-medicines to deal with many skin problems. This review explores the fundamental knowledge on various dermatological properties of medicinal plants of Pakistan and is aimed to provide a baseline for the discovery of new plants having activities against skin issues.

Material and method: A total of 244 published articles were studied using different research engines like PubMed, Google, Google-scholar and science direct.

Results: Review of literature revealed ethno-pharmacological use of 545 plant species, belonging to 118 families and 355 genera, to combat various skin ailments. Out of these, ten most commonly used plant species belonging to ten different families are documented in this review. It was also found out that ehno-medicines are prepared using various parts of the plants including leaves (28.32\%), whole plant and roots $13.17 \%$ and $10.97 \%$ respectively, in the form of powder (23.5\%) and paste (22.75\%). A total of 13 endangered plant species and ten commercially important plants were recorded.

Conclusion: Medicinal plants of Pakistan have therapeutic effects against several skin problems; however most of medicinal plants are still not evaluated scientifically to support their ethno-pharmacological claim on skin. Dermatological pathogens are recommended to study. Further, the conservational programs should be established for endangered species.
\end{abstract}

Keywords: Medicinal flora, Skin problems, Ethno-medicine, Dermatological pathogens

\section{Background}

History of natural products is as old as human civilizations and so is the Indigenous knowledge, which is handed down to the people from their ancestors through verbal communication; people have been living in close association with plants since time immemorial [1]. The purpose of standardizing traditional remedies is, obviously, to ensure therapeutic efficacy of medicinal plants; whereas the value of ethno-medicinal information in modern pharmacology lies in the development of new drugs. Some modern drugs have been deducted from

\footnotetext{
*Correspondence: alam_yuchi@yahoo.com; alamgeer@uos.edu.pk ${ }^{1}$ Laboratory of Cardiovascular Research and Integrative Pharmacology, College of Pharmacy, University of Sargodha, Sargodha, Pakistan Full list of author information is available at the end of the article
}

folklore and traditional medicines [2]. The origin of the word "Ethnobotany" is accredited to US ethnobotanist "John Harshberger" who described and explained the relationship between people and plants they use in a culture in 1895 [1, 3]. In Sub-continent, Rig Veda (4500$1600 \mathrm{BC}$ ) compiled first record of ethno-medicine [4].

In ancient times, natural products were successfully used to treat different ailments owing to their enhanced acceptability in human society, better compatibility with the body and their natural power to treat ailment via synergistic effects and neutralizing combinations to lessen adverse effects [5]. Medicinal plants are better as compared to synthetic drugs because of minimal adverse reactions [6, 7]. Medicinal plants (trees, shrubs, grasses or vines) can be used in different forms [8] like extracts,

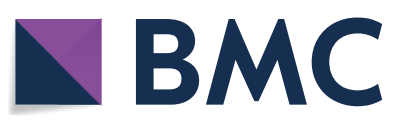

(c) The Author(s) 2018. This article is distributed under the terms of the Creative Commons Attribution 4.0 International License (http://creativecommons.org/licenses/by/4.0/), which permits unrestricted use, distribution, and reproduction in any medium, provided you give appropriate credit to the original author(s) and the source, provide a link to the Creative Commons license, and indicate if changes were made. The Creative Commons Public Domain Dedication waiver (http://creativecommons.org/ publicdomain/zero/1.0/) applies to the data made available in this article, unless otherwise stated. 
in fresh or powdered form, seeds, fruits, vegetable mixtures, etc. [9].

According to an estimate, earth carries 265,000 species of plants but only half of these are yet investigated for their medicinal values and chemical composition. In developing countries, around $80 \%$ of the population depends upon medicinal plants for combating different diseases but this was estimated about a decade ago $[10,11]$ while in developed countries, $60 \%$ of the population uses these plants [6], 40-50\% of the population in Germany, $42 \%$ in the USA, $48 \%$ in Australia and $49 \%$ in France depends upon plants for different health issues [12]. Importance of these medicinal plants can be judged by the fact that at least $25 \%$ of the drugs enlisted in modern Pharmacopoeia are of plant origin [5]. Also about $25 \%$ of the medical prescriptions are based on the substances or analogs of the substances of plant origin [13].

Pakistan occupies $80,943 \mathrm{~km}^{2}$ area and lies between $60^{\circ} 55^{\prime}$ to $75^{\circ} 30^{\prime} \mathrm{E}$ longitude and $23^{\circ} 45^{\prime}$ to $36^{\circ} 50^{\prime} \mathrm{N}$ latitude [14], and has altitude ranges from 0 to $8611 \mathrm{~m}$ with a mixed climate zones; has a large biodiversity of the medicinal plants. Pakistan is blessed with 6000 species of higher plants, of which 600-700 are used medicinally [15], out of these 6000 species, half (3000 species) are reported from Northern areas out of which 124 species have medicinal importance [16, 17], 4940 flowering plants are native to Pakistan (if cultivated flowering species are included figure turns 5738) [14]. Unfortunately only $10 \%$ of the total plant species in Pakistan have reported medicinal values [18].

In Pakistan, a large population uses folk medicines and it has become a definite part of its cultural heritage [19]. In early 1950s, most of the health concerned issues were treated using traditional indigenous experiences by more than $84 \%$ of the population of Pakistan but now this practice is limited to only remote areas of the country [6, 20, 21]. In 1958, Hocking also reported same percent (84\%) of Pakistan population depending upon traditional medicinal plants for treating different ailments. In 1983, $63 \%$ of the population in Pakistan, especially in villages, was reported to use herbal medicines prescribed by the traditional prescribers [22]. Knowledge on the use of medicinal plants is enormous but if this traditional knowledge is not rapidly researched and recorded, indications are that it will be lost with succeeding generations [23].

Skin, the most diverse organ of the human body, is very important for aesthetic reasons and health issues. Skin diseases not only give unfavorable looks but also pushes the patient into psychic conditions [24]. It has been estimated that skin diseases account for $34 \%$ of all occupational disease [25]. Despite of all the developments in the medical science, it is still complicated to manage skin diseases specifically in developing countries, due to the fact that health care workers lack training in skin care and skin diseases, which have been of major concern, recently, due to their association with the Human Immunodeficiency Virus and Acquired Immunity Deficiency Syndrome (HIV/AIDS) [26]. Since human civilization, plants are used to treat major skin issues like wounds, cuts and burns [27]. In a study, it was documented that $80 \%$ of the Indian population uses ethno-medicines to deal with skin problems and $50 \%$ of the medicinal plants used against skin problems are restricted to forest [28].

This review is an attempt to summarize utmost possible information on ethno-medicines and pharmacology of the plants used in Pakistan to cure skin diseases. This study was aimed to investigate the ethno-medicinal uses of the plants of Pakistan to treat various skin conditions. We were interested in gathering the answers of the following questions in particular: Which plant species are most commonly used traditionally for skin problems? Which skin conditions are most commonly treated using ethno-medicine? Which parts of medicinally important flora of Pakistan are used against skin diseases? What are the recipes for preparing and applying the ethno-medicines? Above all, the review will identify gaps in the current knowledge that will provide a baseline for further research activities. Also, the review is aimed to highlight the area of Pakistan still need to be investigated.

\section{Data collection and analysis}

Published papers were retrieved from the online bibliographical database latest till June 2015, search engines included: PubMed, Google, Google.scholar, IUNCredlist, druginfosys and sciencedirect. Inside the database, we used the keywords like traditional plants for skin, ethnobotany of Pakistan, ethno-medicine, traditional uses of plants, indigenous plant knowledge, plants used in ethno-pharmacology. While reviewing the literature, focus was on the plants with the potential traditional usage against various diseases of skin. In total, 244 articles on Indigenous plants of Pakistan published in English language were reviewed for this study for the period March 2015 to December 2017. Articles selected for this review contain plants that were (i) native to Pakistan with some wide distribution (ii) traditionally used in Pakistan for treating skin diseases; only those plants were selected that have ethno-pharmacological evidence for skin treatment. A master document was formulated enlisting indigenous medicinal plants of Pakistan used by the local inhabitants for the treatment of several skin ailments. Master list constituted vernacular name of the medicinal plants along with the family name, part used, mode of preparation, life form and skin conditions against which 
the plant is being used. All the data were summarized into 6 tables and 9 figures.

As this review is written after consulting a large number of articles, only references are provided in it due to vey diversified data.

The data collected were grouped into 26 categories on the basis of skin conditions; 28 categories based on families plant belong to; 7 categories based on mode of preparation of medicine, 30 categories based on the part used, 9 categories based on habit of plants and 6 categories based on the region the plant grows.

Plants reported in more than one region of Pakistan were enlisted only once for making the final list of medicinal plants. Conservation status was evaluated following IUCN red list categories version 3.1 and the herbal products registered in Pakistan and economical importance of the plants was estimated by consulting druginfosys.com and scientific literature respectively.

\section{Taxonomic problems}

Several taxonomic problems were observed in the development of this manuscript. Entirely, we documented 10 plant species most frequently used by the people of Pakistan against skin diseases, there were some spelling mistakes in family names, botanical names, publication and authors, which were also verified according to "http:// www.google.com", "http://www.tropicos.org" and "http:// www.plantlist.org".

\section{Results and discussion}

The present review revealed ethno-medicinal use of 545 plant species belonging to 118 families and 355 genera to cure various skin diseases, 10 plant species belonging to different genera and families which were most commonly used in different regions of Pakistan against several skin ailments are documented in this review (Table 1).

\section{Distribution of plants in different regions of Pakistan}

Pakistan holds rich diversity of medicinal plants used against various ailments. The present review reported 545 plants from different regions of Pakistan being ethno-medicinally used for treating various skin problems. Majority of 278 plants were reported from Punjab belonging to 78 families followed by 204 plants from Gilgit from 73 families, 201 from Kashmir belonging to 74 families, 187 from KPK from 73 families, 47 from Sindh from 27 families and 25 from Balochistan belonging to 14 families. Many regions are still un-investigated; a list of investigated as well as un-investigated areas of Pakistan is given in Table 2. Many of the plants and hence families were used in more than one region; those plants and their families were counted just one time when enlisting for overall plants of Pakistan. The distribution of plants and their families in different regions of Pakistan, according to their use in skin conditions is shown in Fig. 1.

\section{Medicinally important families and genus against skin ailments}

A total number of 118 families were studied and out of them 10 families were documented in this review. Among these families, Asteraceae (8.99\%) is the most commonly used family followed by Fabaceae (4.58\%), Poaceae (3.73\%), Laminaceae and Ranunculaceae (3.39\% each), Rosaceae (3.22\%), Euphorbiaceae and Solanaceae (3.05\%), Polygonaceae (2.88\%), Boraginaeae (2.71\%), Papilionaceae and Amaranthaceae (2.37\% each), Apocynaceae (2.20\%), Cucurbitaceae and Malvaceae $(1.86 .5 \%$ each), Chenopodiaceae, Salicaceae and Liliaceae (1.69\% each), Apiaceae and Brassicaceae (1.52\% each), Moraceae, Scrophulariaceae and Zygophyllaceae (1.35\% each) Capparidaceae, Convolvulaceae and Rutaceae (1.18\% each), Cyperaceae, Rhamnaceae, Saxifragaceae and Tamaricaceae (1.01\% each) and some other 87 families (30.39\%).

The results, in terms of percentage, of commonly used families are represented in Fig. 2.

Asteraceae holds the top position among the families used in ethno-medicines which indicates the presence of effective bioactive ingredients in the members of this family [29]. Lamiaceae and Asteraceae are the most frequently used families in ethno-medicine [30]. It was reported that Asteraceae family is the most diverse family found in all the habitat and regions except in Antarctica and it was not a new finding about Asteraceae family holding highest position among the traditionally important families, it was further concluded that this prevalence is due to high quantities of active secondary metabolites present in this family and also because this family includes a large number of species [31].

Euphorbia is the genera having highest number of species (11 ssp.) used to fight skin problems followed by Artemisia with 9 ssp., Ficus and Salix (8 ssp. each), Solanum (7 ssp.), Impatiens, Polygonum, Rumax, Saussurea, Ziziphus (6 ssp. each), Clematis, Datura, Tamarix, Vernonia (5 ssp. each), 15 genera with 4 ssp., 23 genera with 3 ssp., 72 genera with 2 ssp. and 224 genera with 1 ssp. used to combat different skin ailments.

Medicinally important genera along with the number of species used effectively against skin ailments in terms of percentage are graphically represented in Fig. 3.

Euphorbia taking the top place in the genera used most frequently in ethno-medicine due to the reason that it is the largest genus of family Euphorbiaceae with 1600 reported species [32]. 


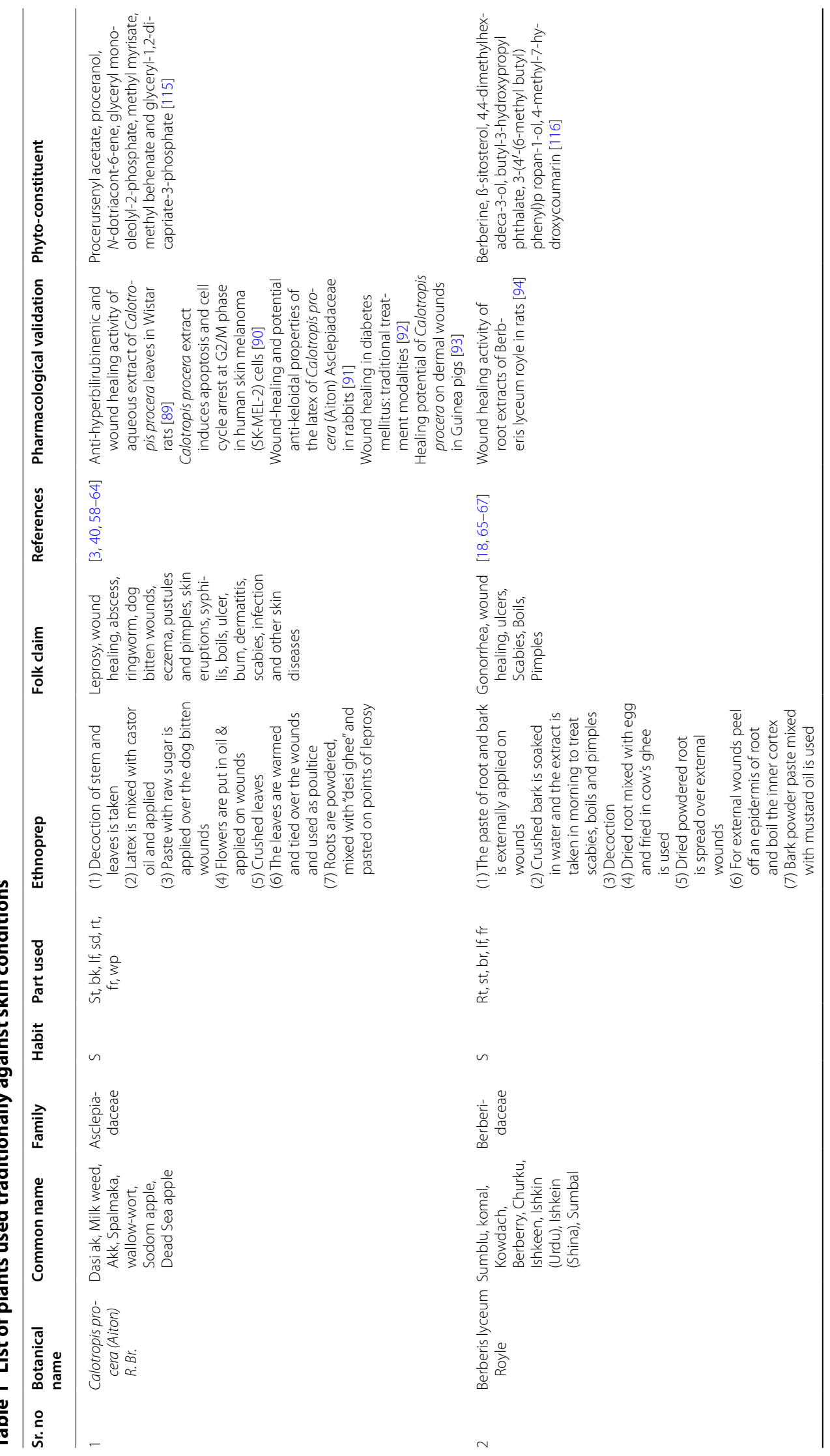




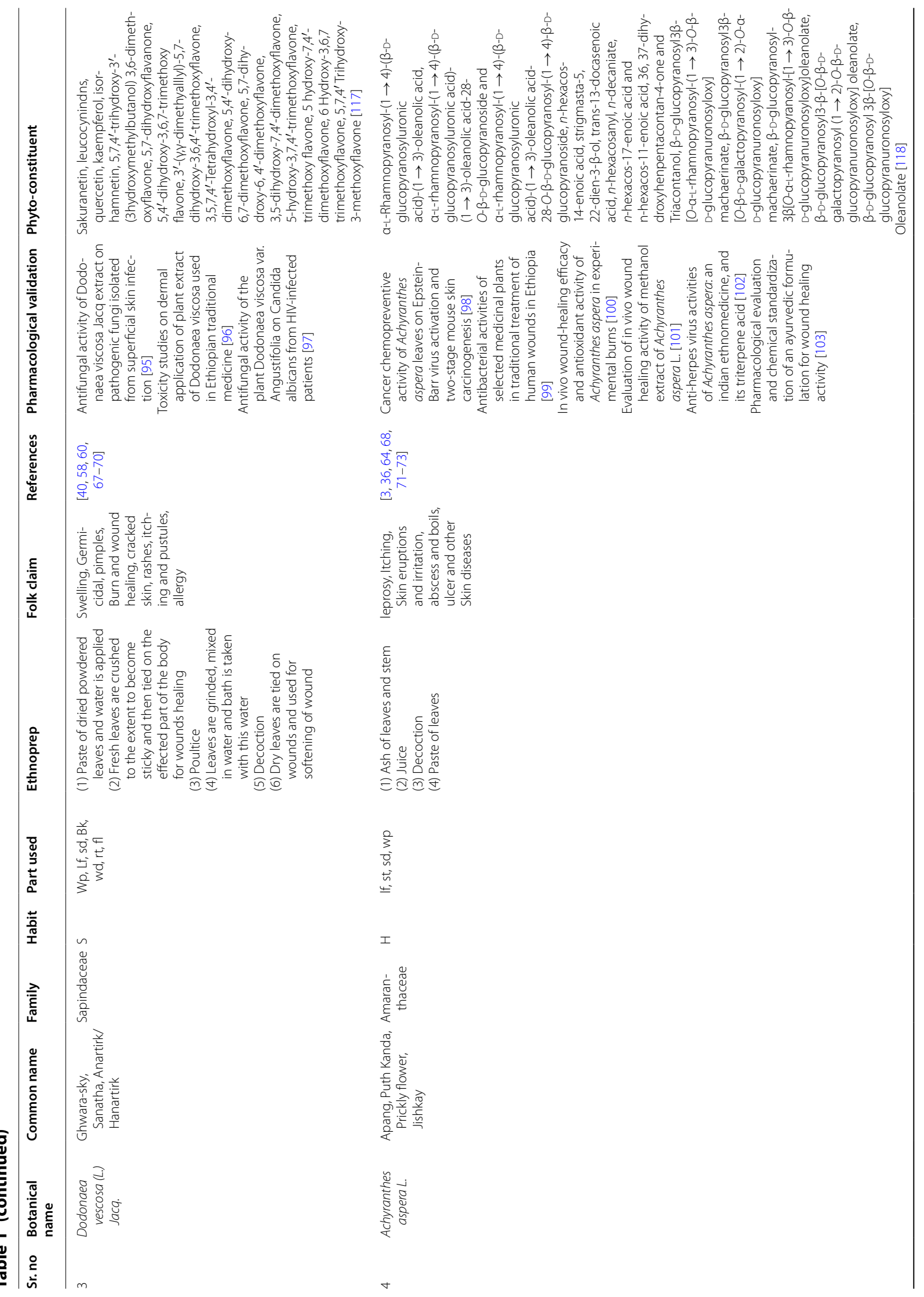




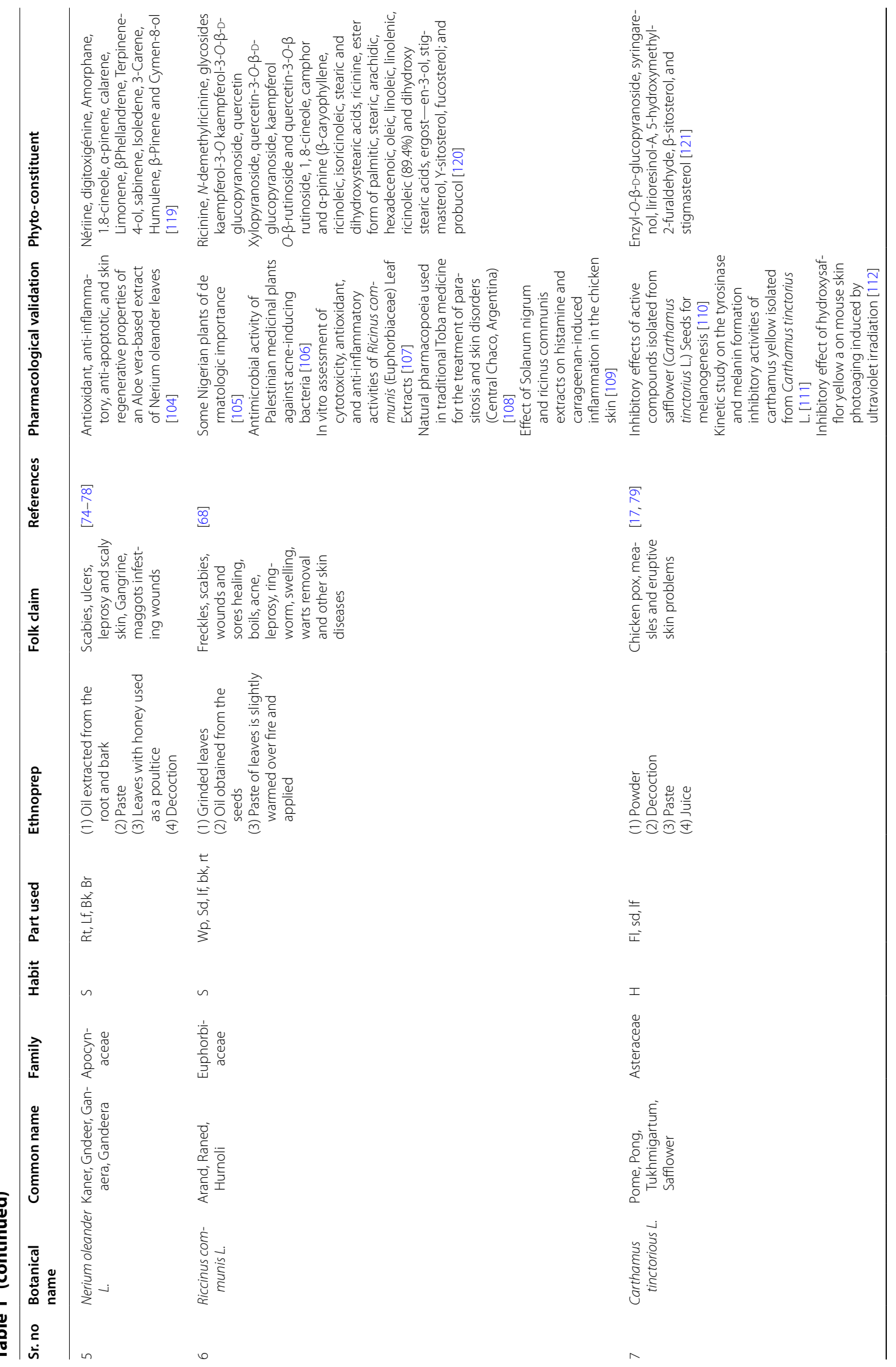




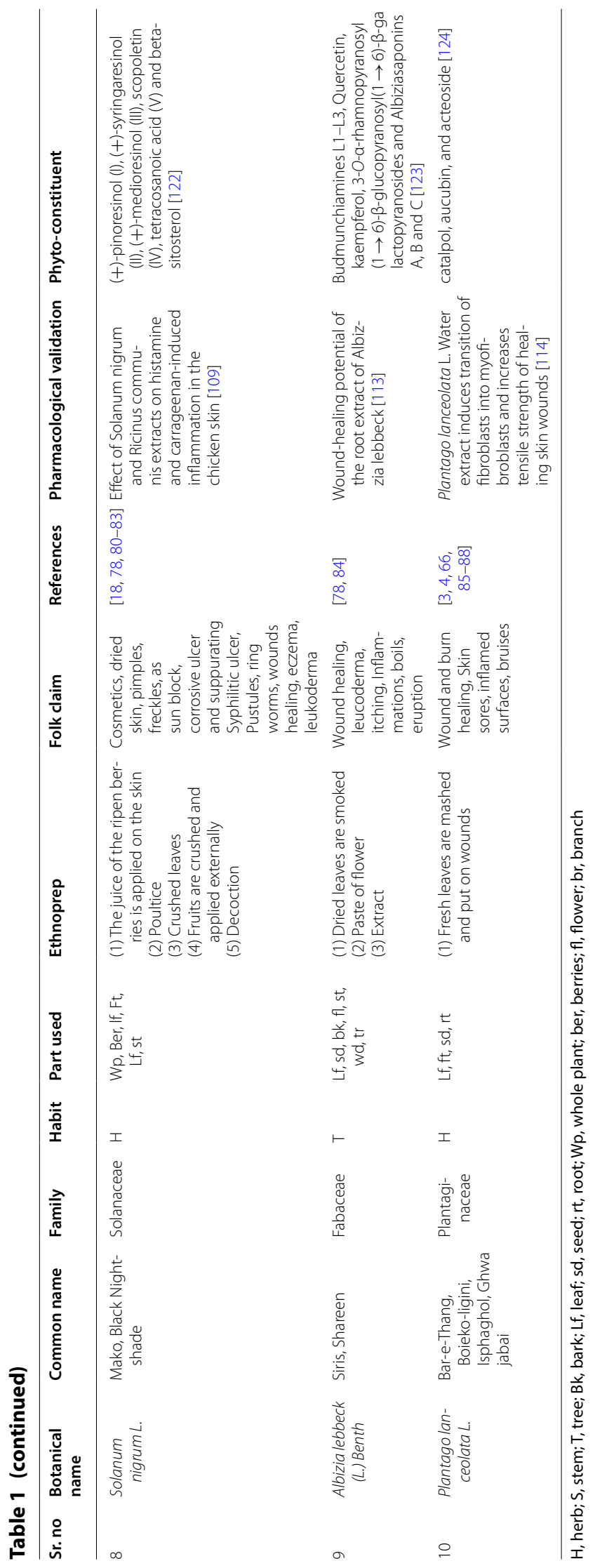


Table 2 Investigated and under-investigated districts for ethno-botanical studies

\begin{tabular}{|c|c|c|}
\hline Province & Investigated districts for ethno-botanical studies & Under-investigated districts for ethno-botanical studies \\
\hline Punjab & $\begin{array}{l}\text { Attock, Bahawalnaga, Bahawalpur, Bhakkar, Chakwal, Dera } \\
\text { Ghazi Khan, Faisalabad, Gujranwala, Gujrat, Jhang, Jhelum, } \\
\text { Kasur, Khushab, Mianwali, Multan, Muzaffargarh, Narowal, } \\
\text { Nankana Sahib, Pakpattan, Rajanpur, Rawalpindi, Sahiwal, } \\
\text { Sargodha, Sialkot, Toba Tek Singh, Vehari }\end{array}$ & $\begin{array}{l}\text { Chiniot, Hfizabad, Khanewal, Okara, Rahim Yar Khan, Sheikhu- } \\
\text { pura }\end{array}$ \\
\hline Khyber Pakhtunkhwa & $\begin{array}{l}\text { Abbottabad, Bannu, Battagram, Buner, Chitral, Dera Ismail } \\
\text { Khan, Haripur, Karak, Kohat, Upper Kohistan, Lakki Marwat, } \\
\text { Lower Dir, Malakand, Mansehra, Peshawar, Swat, Upper Dir, } \\
\text { Lower Kohstan }\end{array}$ & $\begin{array}{l}\text { Charsadda, Hangu, Mardan, Nowshera, Shangla, Swabi, Tank, Tor } \\
\text { Ghar }\end{array}$ \\
\hline Sindh & $\begin{array}{l}\text { Ghotki, Jamshoro, Karachi, Kairpur, Sanghar, Sukkur, Tharparkar, } \\
\text { Thatta, Karachi West }\end{array}$ & $\begin{array}{l}\text { Badin, Dadu, Hyderabad, Jacobabad, Kashmore, Larkana, Matiari, } \\
\text { Mirpurkhas, Naushahro Firoze, Shaheed Benazirabad. Kambar, } \\
\text { Shahadkot, Shikarpur, Tando Allahyar, Tando Muhammad } \\
\text { Khan, Umerkot, Sujawal, Karachi Central, Karachi East, Karachi } \\
\text { South, Korangi, Malir }\end{array}$ \\
\hline Sindh & Ghanche, Skardu, Astore, Diamer, Ghizer, Gilgit, Hunzanagar & Kharmang \\
\hline Gilgit Baltistan & $\begin{array}{l}\text { Muzaffarabad, Hattian, Neelum, Mirpur, Bhimber, Kotli, Poonch, } \\
\text { Bagh, Haveli, Sudhnati }\end{array}$ & \\
\hline
\end{tabular}

\section{Common skin diseases in Pakistan}

In this review, it was found out that most of the plant species were used to treat more than 1 disease/condition of skin. Total 26 skin conditions were reviewed which were treated using ethno-medicine. Most common of them was wound healing (17.064\%) followed by boil healing $(8.72 \%)$, postules or pimples (5.83\%), eczema (5.01\%), ulcer (4.579\%), burn (4.51\%), Ringworm (3.889\%) and scabies (3.889\%).

These most commonly treated skin conditions mentioned above are represented graphically in Fig. 4 and total of all the skin conditions treated traditionally are represented in Fig. 5.

Burn, which accounts $4.51 \%$ of the skin conditions treated traditionally in Pakistan is a serious issue globally, De Wet et al. reported increased mortality rate due to burn which has contributed to a serious health concerned issue globally. In South Africa, burn is one of the major reasons of deaths among 5-29 years individuals. Ethno-medicines have great potential to cure different kind of skin diseases $[25,137]$.

Some plants cure more than one skin disease, Curcuma longa and Melia azaderach are the natural resources for curing multiple skin diseases $[33,138]$.

Tabassum and Hamdani concluded that skin conditions can be of thousand types but are categorized into nine categories based on common diseases; rashes, viral infections, bacterial infections, fungal infections, parasitic infections, pigmentation disorder, tumor and cancer, trauma and other conditions (Wrinkles, spider veins and varicose veins) [28]. This review revealed that all these skin conditions are treated traditionally using etho-medicines.
Mabona and Vuuren reported wound healing as a most frequently treated skin condition using ethno-medicine, followed by sores or ulcers. Among the medicinal plants used to combat wounds, Erythrina genus is used most frequently in South Africa with 120 species having their space in the traditional usage against skin conditions particularly in disinfection of wounds. Traditional plants are also used to combat associated condition of wounds including inflammation, urticaria, skin allergies, acne, eczema and psoriasis. Among these associated conditions, eczema is most commonly diagnosed in South Africa and thus most frequently treated with ethno-medicines [34].

\section{Habit}

Growing habits of $42.23 \%$ plants were not available in the previous articles. Common life forms used by traditional healers for the preparation of ethno-medicines include Trees $9.68 \%$, Shrub $11.52 \%$, Herb $34.72 \%$, Creepers and Climbers $0.5 \%$ each, Grass $0.5 \%$ (only 3 plants were a grass), Sedges $0.1 \%$ (only 1 plant was from sedges) as shown in Figs. 6 and 7.

Trees and shrubs are used to prepare majority of herbal recipes as they are accessible round the year, followed by utilization of herbs which might be related to their easy collection methods, higher abundance and efficacy in curing ailments as compared to other life forms [30]. Khan et al. reported shrubs and trees as most commonly used life forms in ethno-medicines due to the their availability around the year with the minimum seasonal variation [35]. Ahmad et al. stated that herb is used in ethno-medicines due to their abundance and easy availabilty in most of the aresa of the world [36]. 


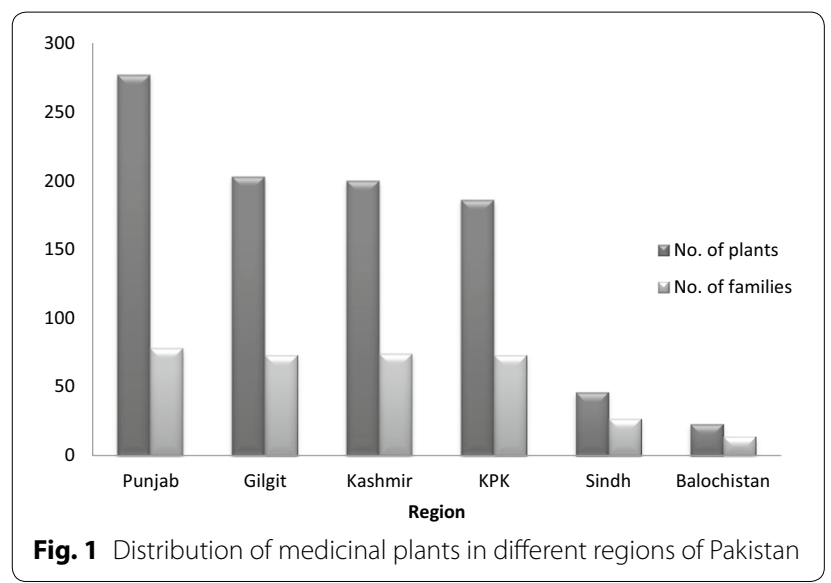

Part used

Ethno-medicines mostly consisted of plant parts such as leaves, roots, fruits, seeds, flowers, stem, bark and some other parts of the plants listed below. Traditional knowledge on the effectiveness of different plant parts could have been established through trial and error basis along with observations such as taste, smell and texture. This study revealed that leaves $(28.32 \%)$ were the most common part of indigenous plants used in different preparations of ethno-medicines for the treatment of skin diseases followed by whole plant (13.17\%), roots $(10.97 \%)$, fruits $(9.89 \%)$, flowers $(6.79 \%)$, stem (5.78\%), bark (5.60\%), Shoos and latex (1.37\% each), aerial parts and wood (1.07\% each), branches $(0.89 \%)$,

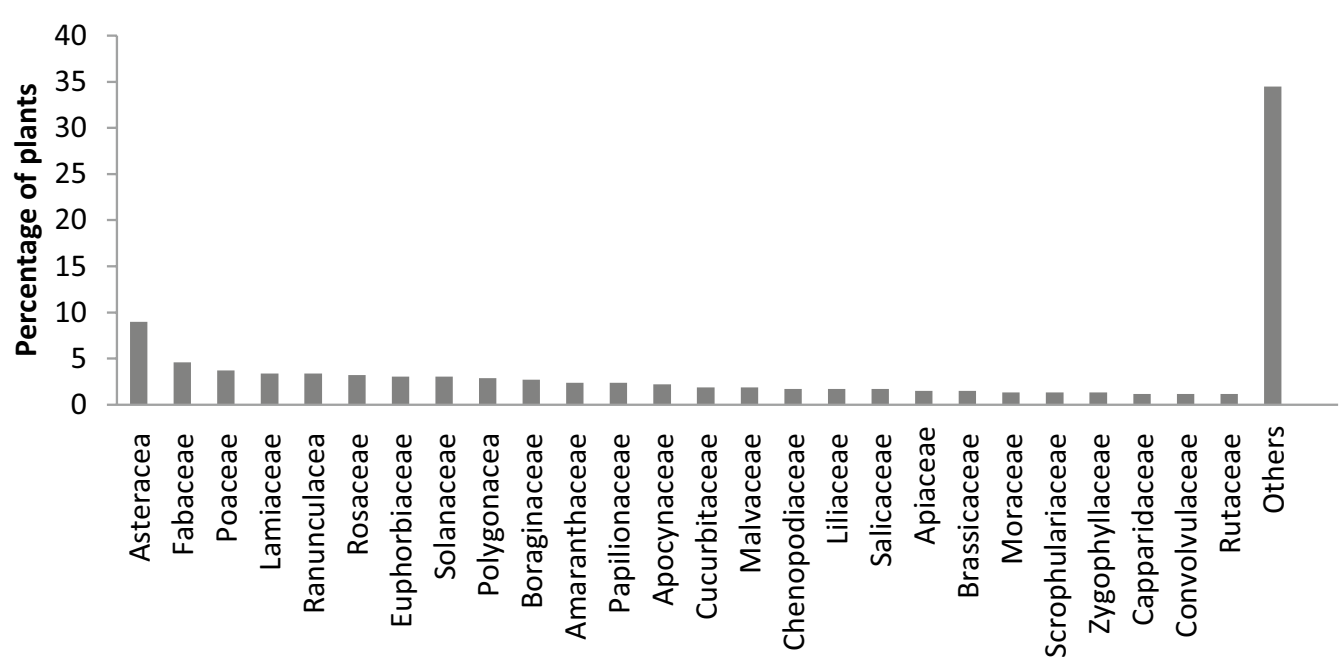

Fig. 2 Families of plants active against skin ailment

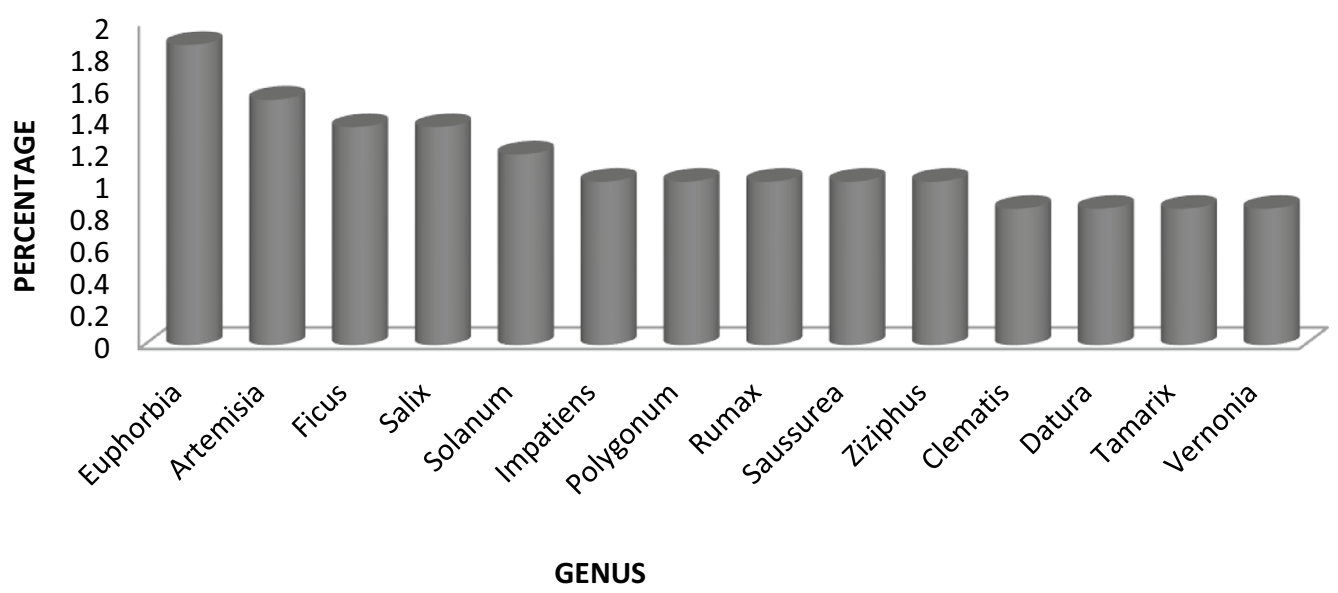

Fig. 3 Common genera used for skin diseases 


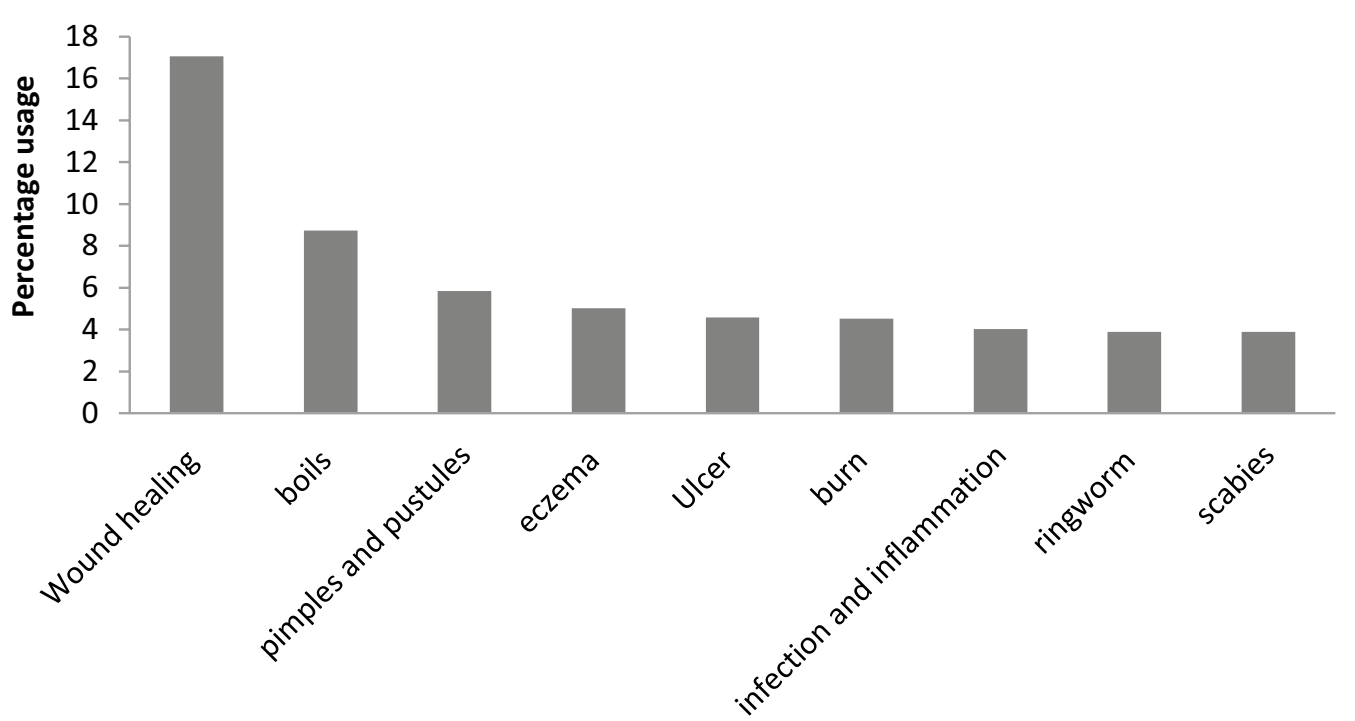

Fig. 4 Common skin diseases treated traditionally

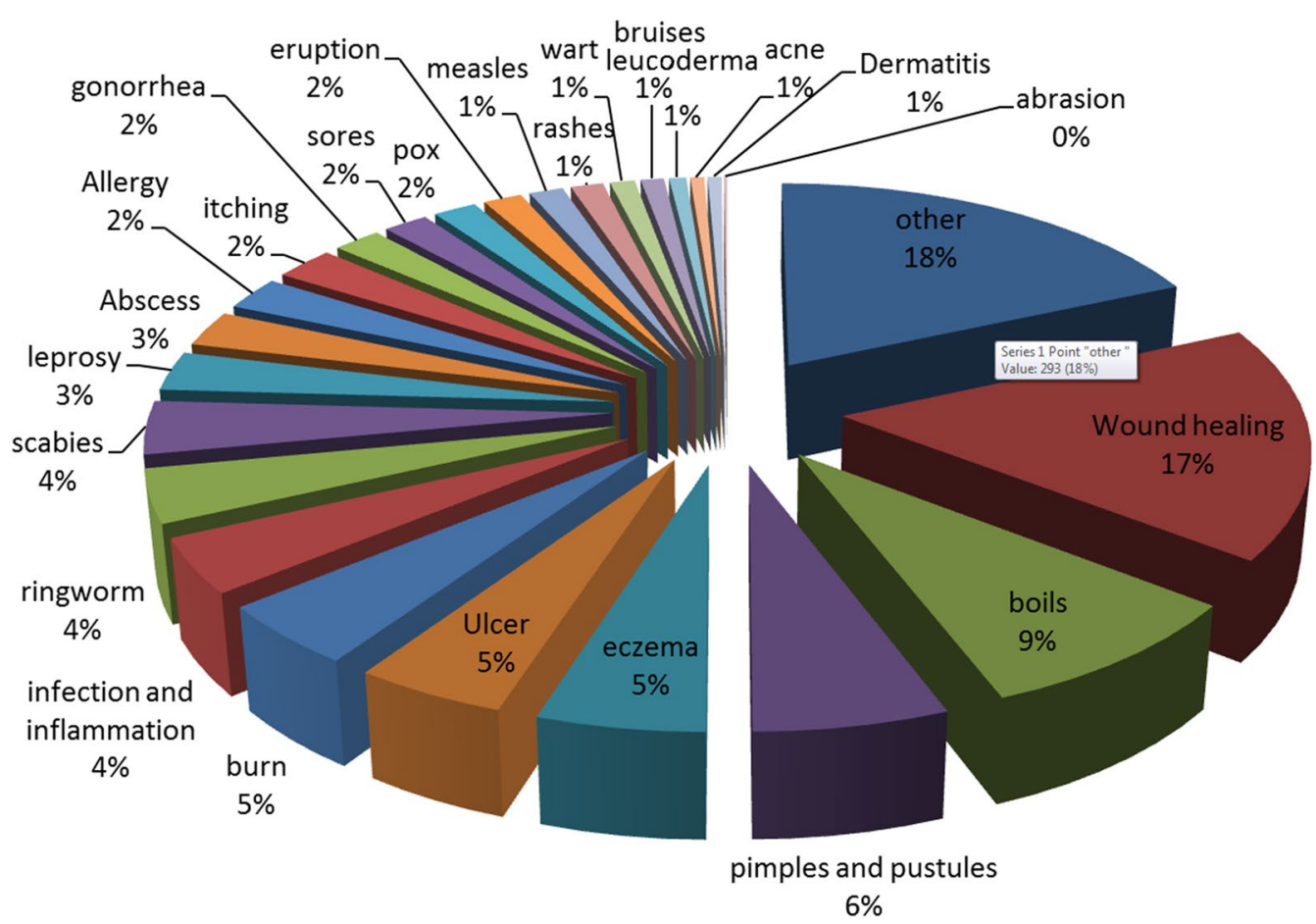

Fig. 5 All the skin diseases treated traditionally in Pakistan

Berries $(0.77 \%)$, rhizomes $(0.71 \%)$, gum $(0.65 \%)$, resins and bulb (0.41\% each), pod (0.29\%), pulp and tubers $(0.23 \%$ each), milky acrid, nut, inflorescent, twigs (0.17\% each), sap, fronts, trunk ( $0.11 \%$ each), husk and gall (0.05\% each) (Fig. 8).
Leaves were the most commonly used plant part in ethno-medicine, this is due to the ease of processing them into a digestible paste and have less conservational issues than the collection of roots, bark, stem or the whole plant and also because leaves does not affect the 


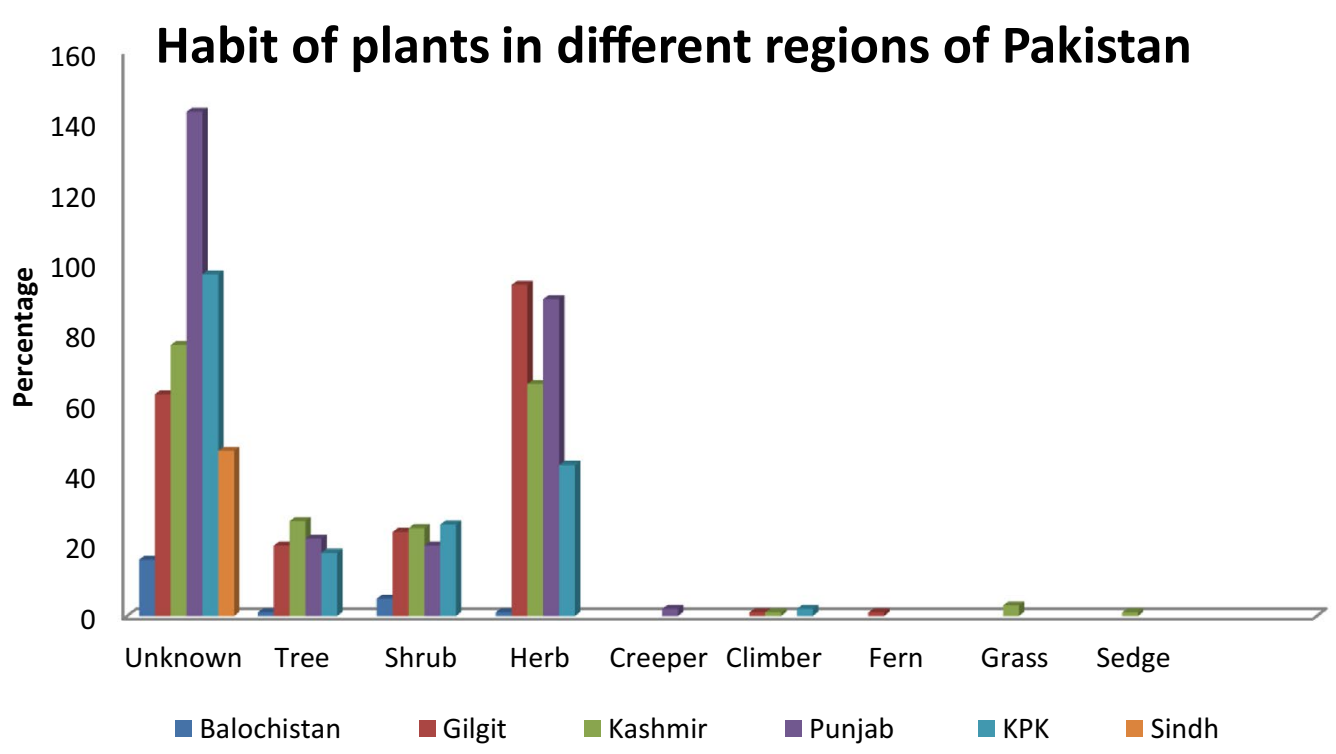

Fig. 6 Habit of plants in different regions of Pakistan

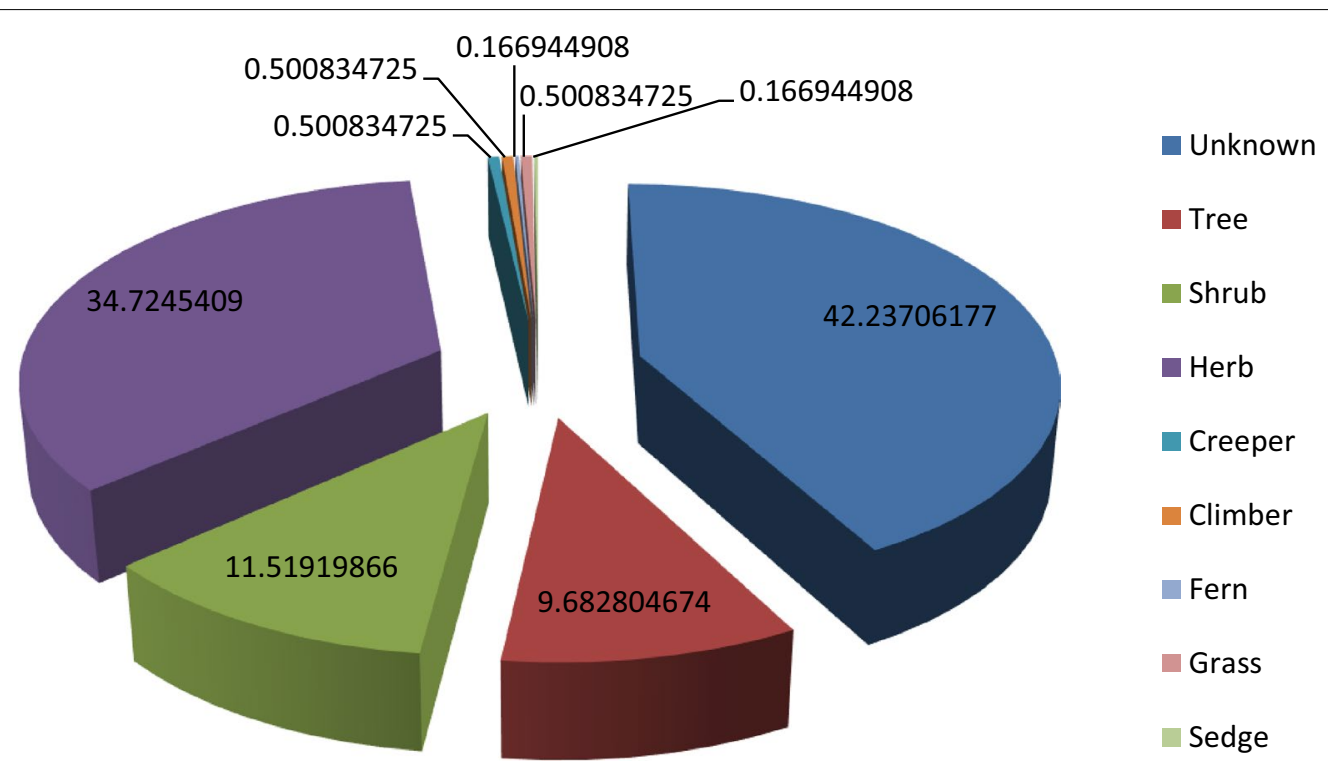

Fig. 7 Habit of plants in Pakistan

life cycle of the plants [29], further the life form of the plant is not effected by the collection of leaves [37] and also due to the reason that leaves contain photosynthate which might have some medicinal value [38]. Ayyanar and Ignacimuthu reported leaves as most frequently used plant part (accounting 50\%) to prepare ethno-medicines in Kani Tribes, India [39].

Whole plant and roots are other frequently used plant parts probably due to bioactive components enriched in these parts. However, their excessive use is detrimental for their survival since whole plant has to be uprooted. Not only roots, even the use of more than one plant part for medicinal purpose has put these plants to extinction risk owing to damage inflicted on the plants [40]. 


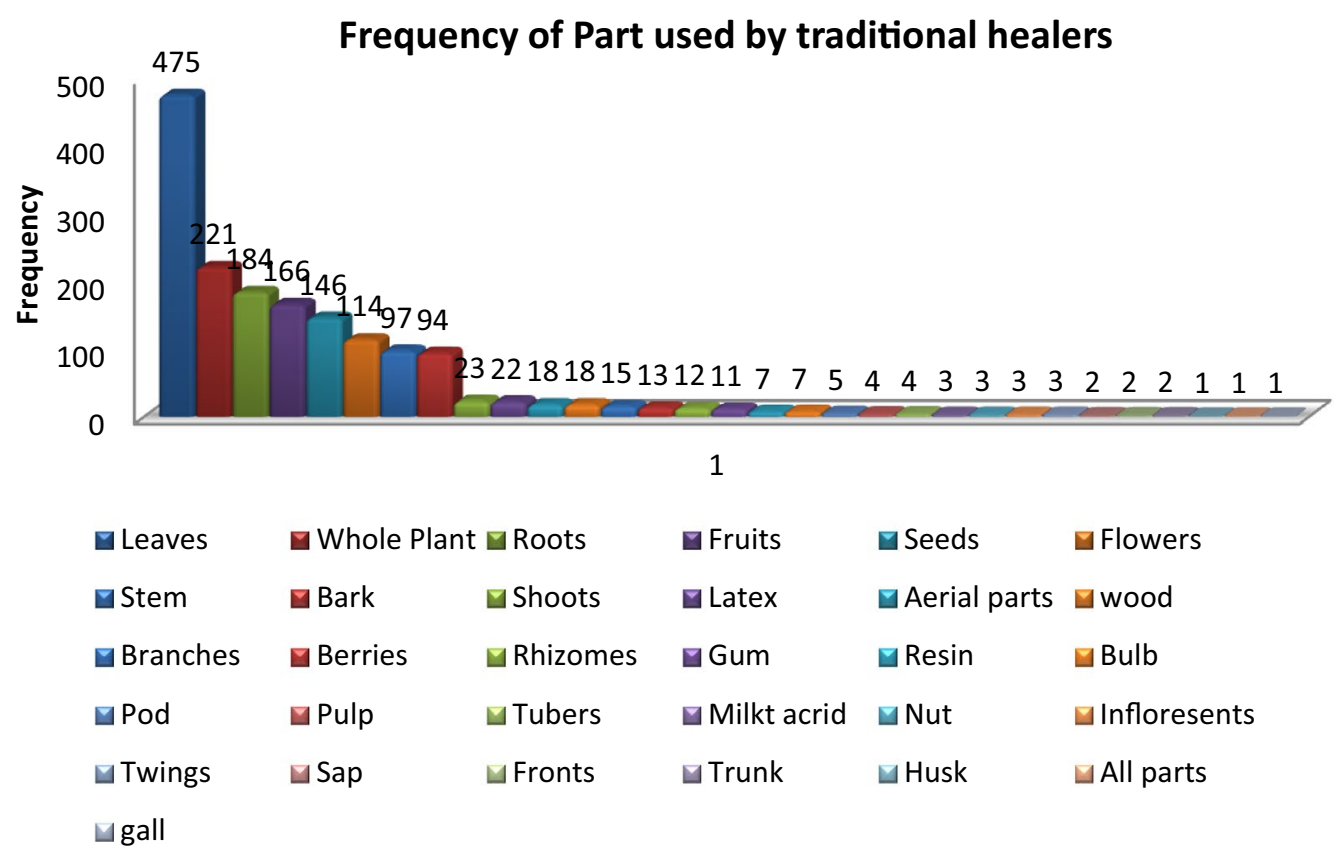

Fig. 8 Part used by traditional healers to prevent different skin ailments

\section{Mode of preparation}

Herbal preparation is made by using different plant parts like whole plant, leaves, roots, stem, fruits, flowers, barks, berries and seeds.

Different modes of preparation are used for different plants by using various parts by the native people; this study showed $23.5 \%$ ethno-preparations were used in powdered form, $22.7 \%$ paste, $16.37 \%$ decoction, $12.62 \%$ juice, $8.75 \%$ poultice, and $8 \%$ each extract and infusion and $16.25 \%$ were not mentioned in literature.

Different modes of preparation of the plants are shown in Fig. 9.

The missing information regarding mode of preparation of the ethno-medicine was also reported by

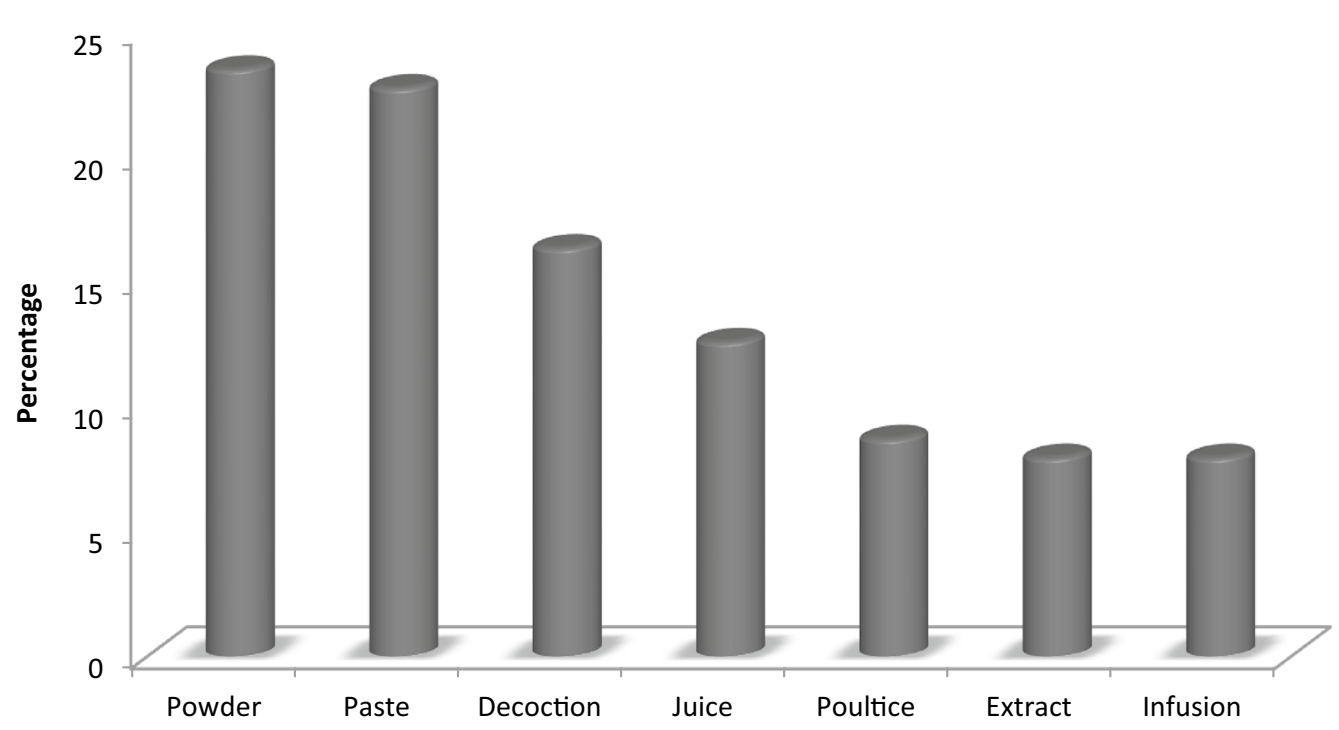

Fig. 9 Mode of preparation of plant 
Farnsworth who indicated the published studies include raw list of plants and only a small number of manuscripts reports the mode of preparation while the rest indicates the part used in treating a particular ailment [41].

Literature revealed that plants can be used in different ethno formulations depending upon the sort of skin disease to be treated and the type and part of plant selected to treat the disease. The ethno-formulation used for skin condition may include powder, paste, plant juice, ointment, poultice, extract, decoction or infusion [42, 43].

Decoction and infusion are frequently used in ethnomedicine due to the ease of preparation and because water is used as a solvent in these formulations, which is easily available [34]. Felhaber reported that ethno-medicines can be given orally or applied topically. Though both the routes can be used but topical application is common as well as effective as it ensures direct contact of active constituents of plant with the site of action (skin) and also because it gives a quick relief [44].

\section{Combined ethno-preparation}

Medicinal plants are used in combination with other medicinal plants, with vegetable oils (mustard oil, apricot oil etc.) and/or with the nutrients (milk, ghee etc.). People of Pakistan still rely on synergistic interactions of plants and supportive components like oil and milk to treat skin diseases.

These supplement ingredients may be used to enhance the effect of the herbal preparations or are simply used to make the preparations palatable. And on the other hand they improve the healing conditions; however, the exact role of these materials in curing the diseases is not clearly known [29].

A number of plant combinations used to treat skin conditions have been reported. The synergistic interaction of medicinal plants have been used since antiquity. Mabona and Van Vuuren reported that medicinal plants are used alone as well as in combination with other plants without any adequate validation of the combination. Plant species like Acorus calamus, Cyathula natalensis, Cyanella lutea, Hypoxis latifolia, Momordica foetida, Pittosporum viridiflorum and Vernonia natalensis have effects on skin when used in combination with other plants but if used alone, they do not have any dermatological effects; they may have potential to treat the additional symptoms associated with skin conditions like fever in skin infection [34].

Plants used in combination with other plants are given in Table 3, plants used in combination with different oils in Table 4 and plants used in combination with nutrients are given in Table 5 .

\section{Endangered species}

Endangered medicinal plants of Pakistan that have got their role in treating skin conditions are discussed in Table 6.

Using the part like roots, rhizomes or bulbs could be a severe threat for reproduction of medicinal plants of the area. The plants collected by using these methods, especially those propagated through rhizome, bulb or corm, need sustainable utilization and conservation strategies. Un-sustainability of harvesting of herbaceous roots is well recognized by conservationists and termed such medicinal plants as highly threatened [40]. Uprooting a plants is the most detrimental method of plant collection, if the roots are not removed completely it can also result in destruction by decreasing water upset and increasing susceptibility of fungal infection. Commercialization is the major cause of extinction of medicinal plants in South Africa which demands over harvesting and thus has taken natural medicinal resources to near extinction [45].

Shanwari suggested to establish protocols to interpret the pattern of plant growth and to accelerate the knowledge about propagation of medicinal plants and avoiding harvesting of wild species in order to save endangered species [15].

Aconitum chasmanthus, A. heterophyllumand, A. violaceum, which are native to Pakistan, India and Nepal [46-48], are harvested for their tubers which constitute Ayurveda drug and for this reason whole plants are uprooted. In 2003 in a CAMP workshop organized at India (Shimla), experts agreed that $80 \%$ of the wild population of Aconitum chasmanthus had declined and therefore it is assessed as "critically endangered species", 70\% of that of A. heterophyllum had declined and it is assessed as "endangered" while $40 \%$ decline of the population of $A$. violaceum has made it a "vulnerable" specie to become endangered. This decline is over a decade but the situation has not improved and therefore the status id still valid [49]. It was observed in a survey in India that collection amount of $A$. heterophyllum has dropped down from $200 \mathrm{~g}$ per person per day to $70-100 \mathrm{~g}$ per person per day in 5 years [50]. Moreover, illegal collection of this specie has let it threatened [51].

Reddy et al. reported that oleo-gum resin tapped from the stems of Commiphora wightii constitutes the wellknown Ayurvedic drug "Guggul" which is consumed in high volumes by the herbal industries of Sub-continent. Field observations over the last several decades have confirmed a severe decline in its wild population, as the shrubs tapped for oleo-gum resin die within 2-3 years. Over the past 84 years (three generation lengths) there has been a decline of more than $80 \%$ in the wild population as a result of habitat loss and degradation, coupled 


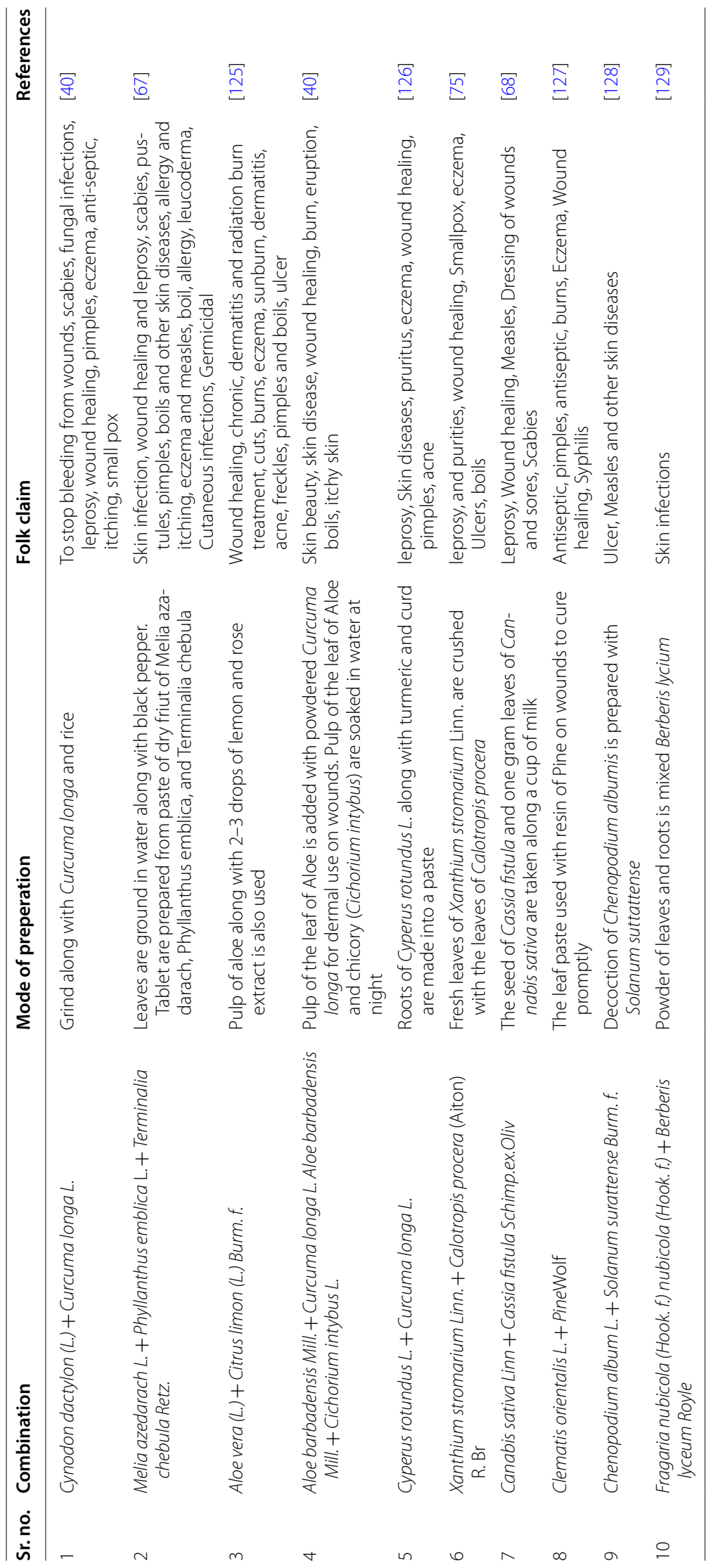




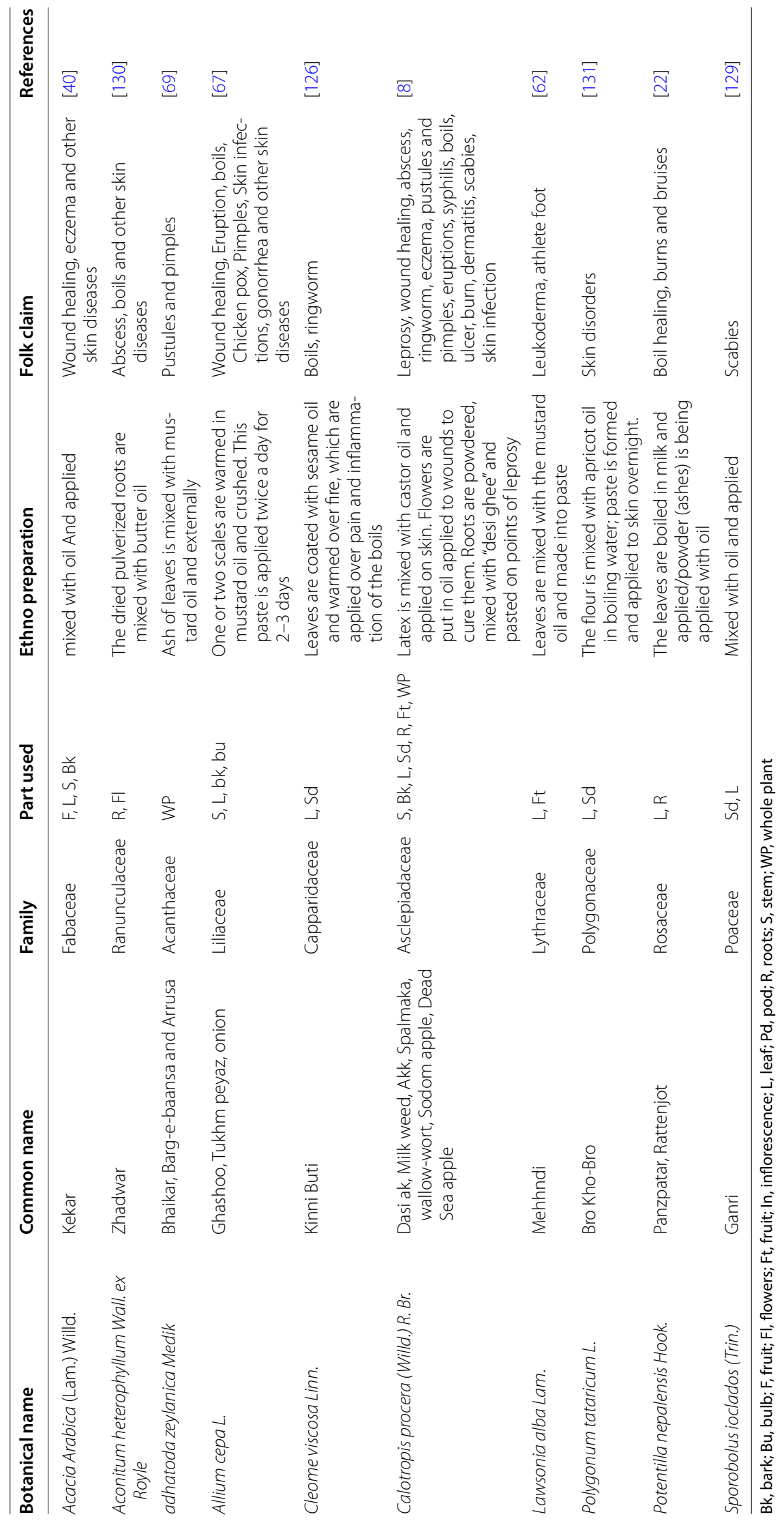




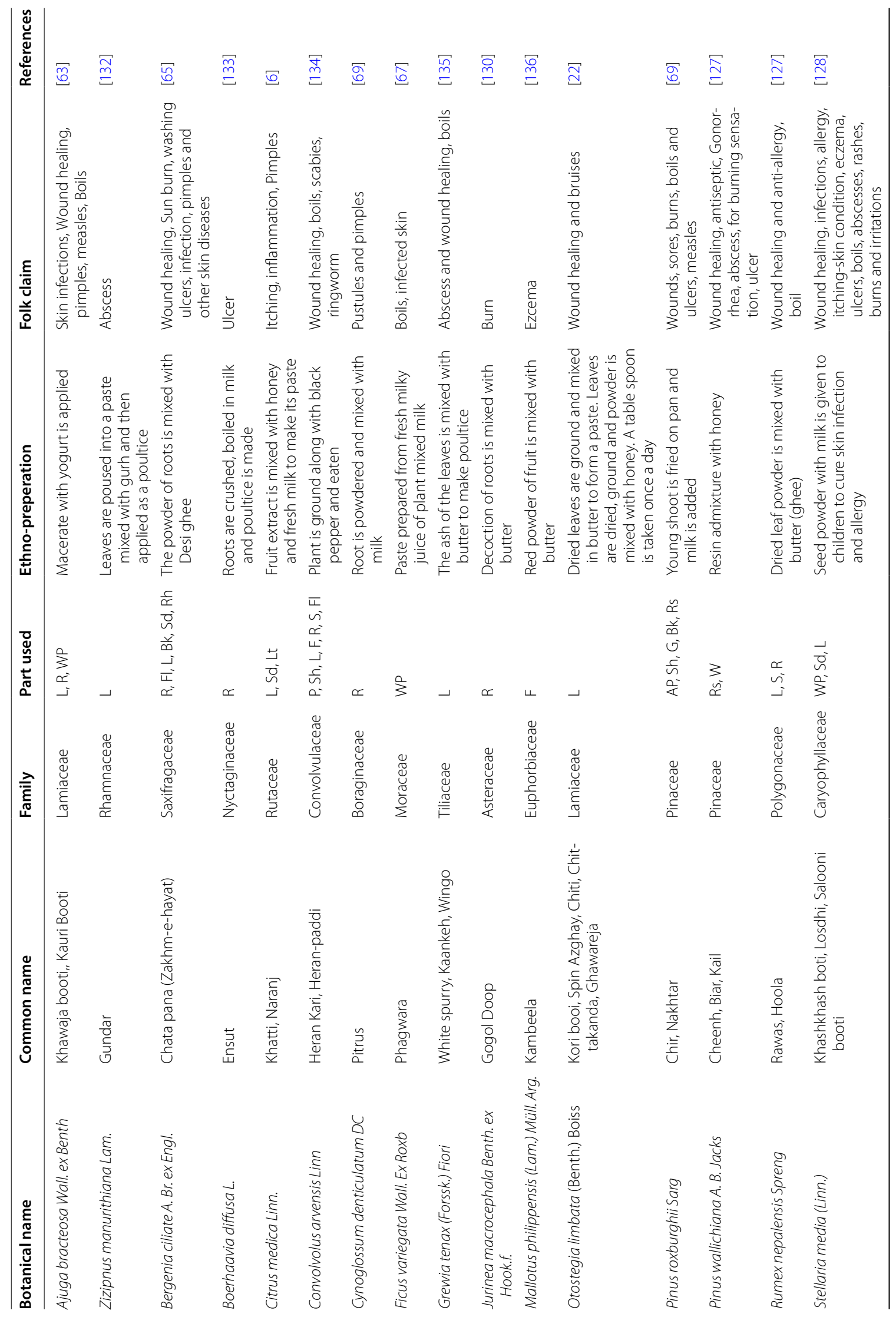




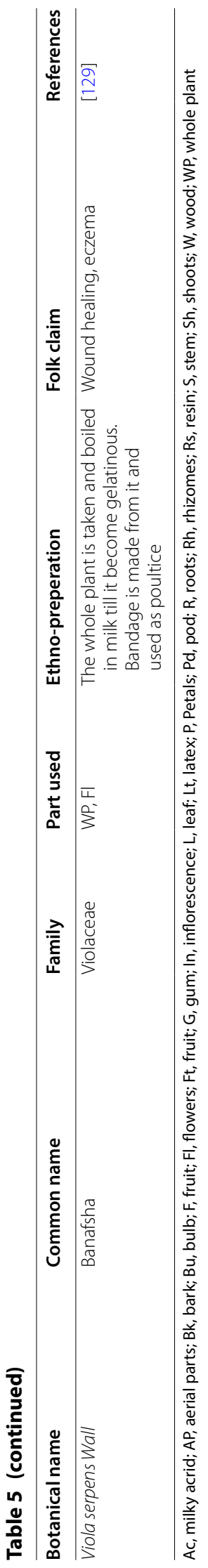




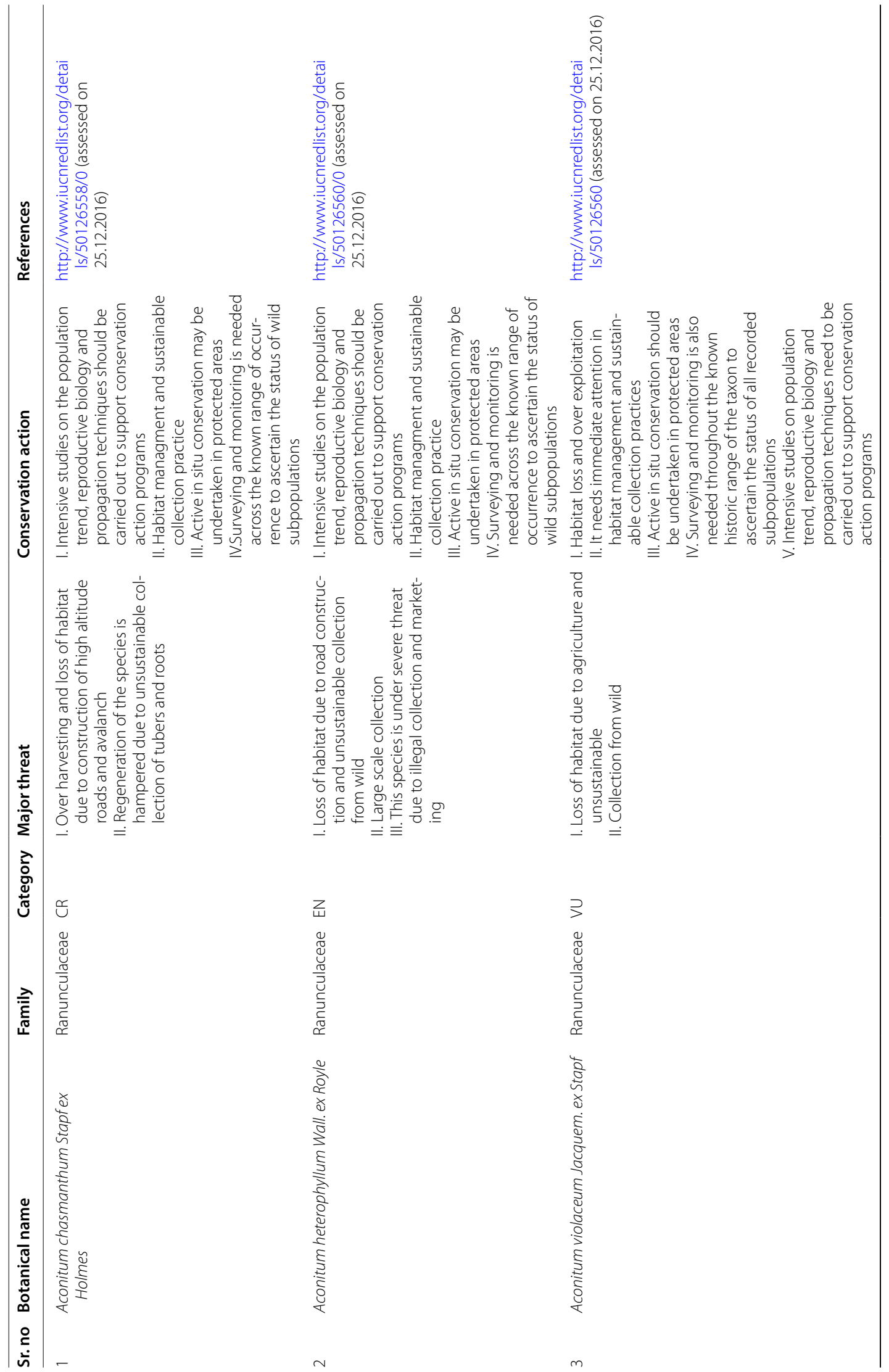




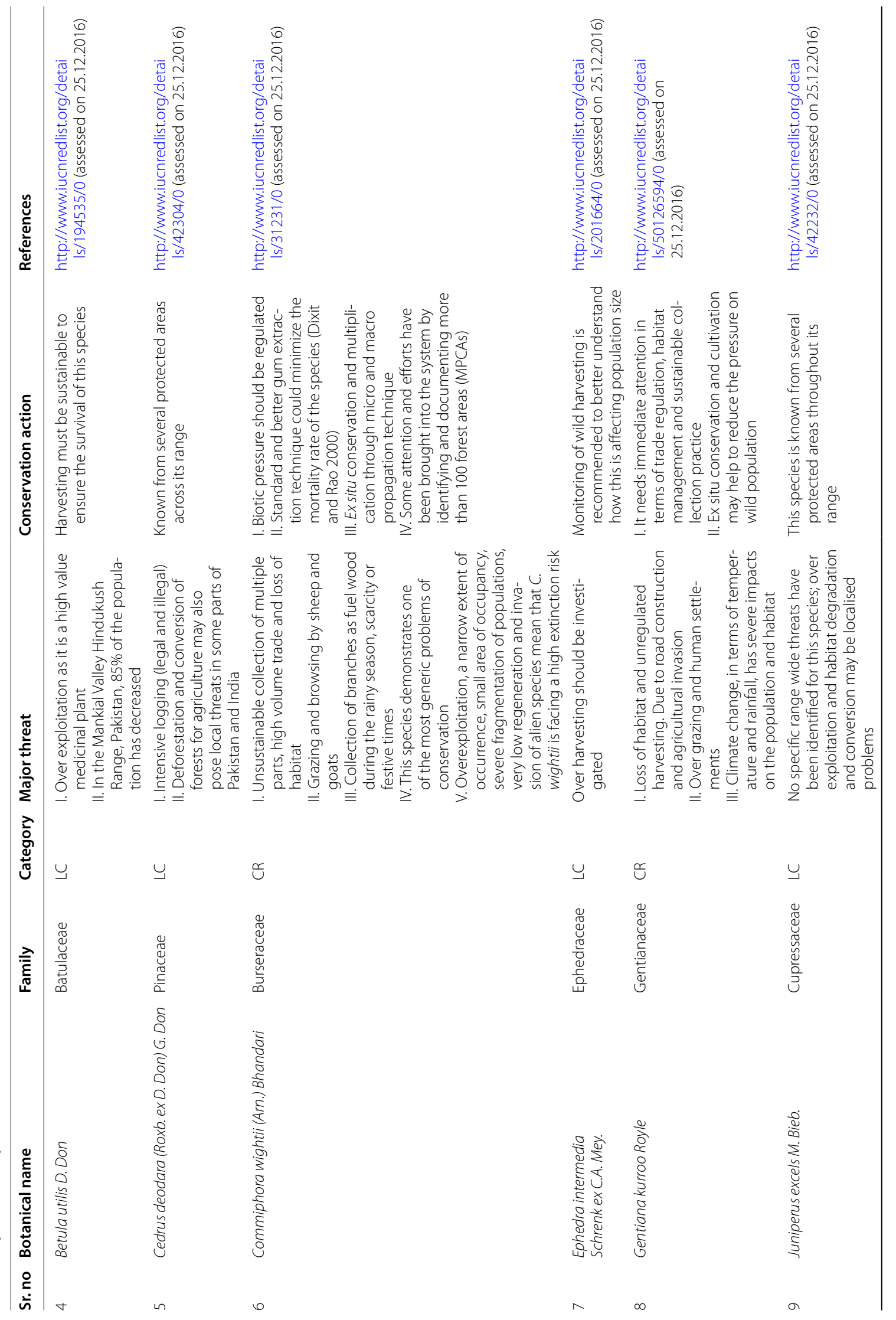




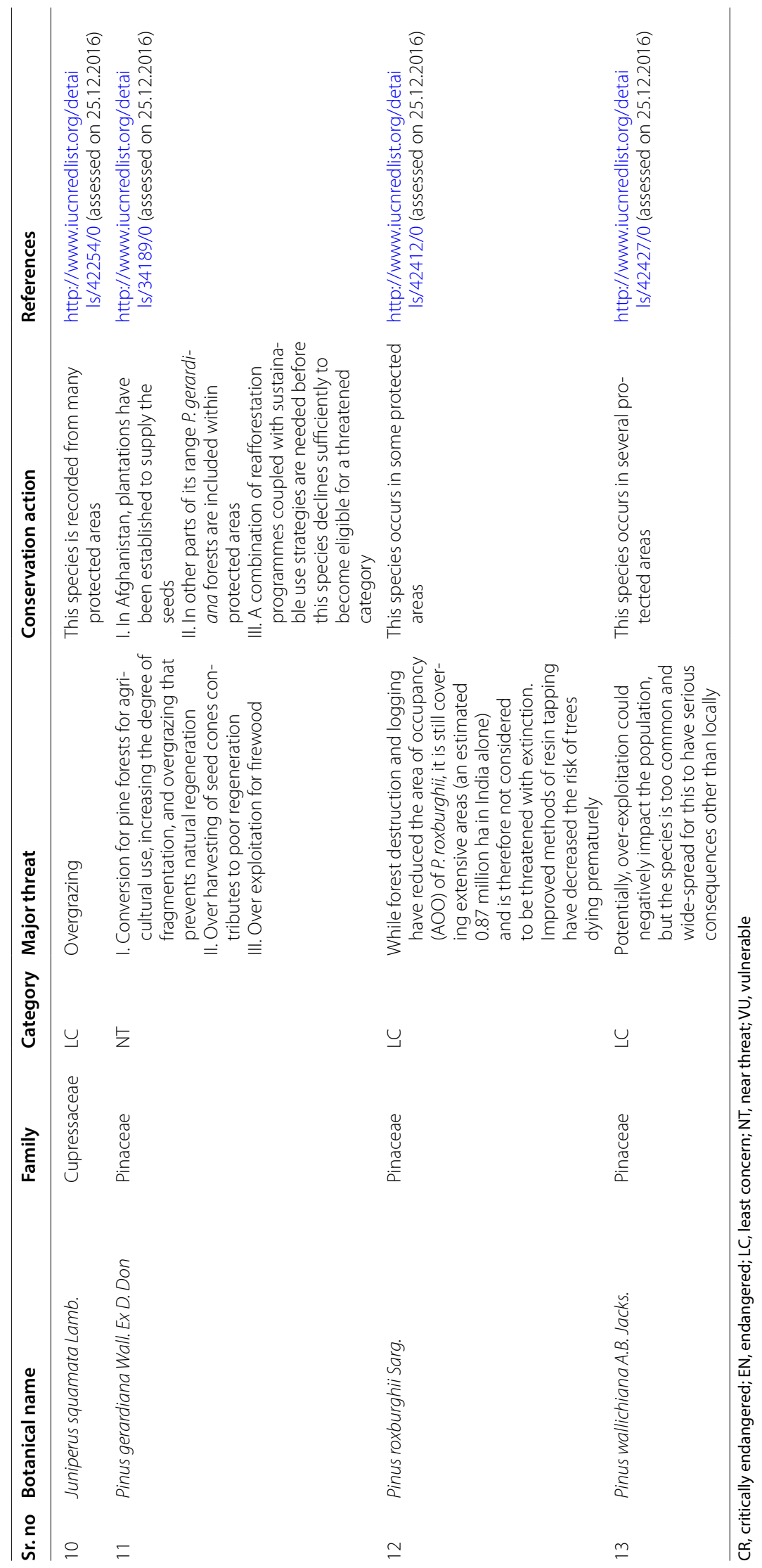


Table 7 List of some commercially available medicinal plants used in Pakistan

\begin{tabular}{|c|c|c|c|c|c|c|}
\hline Sr. no & $\begin{array}{l}\text { Botanical } \\
\text { name }\end{array}$ & Brand name & Manufacturer & Ingredients & Dosage form & Dosage \\
\hline 1 & $\begin{array}{l}\text { Calotropis pro- } \\
\text { cera (Willd.) } \\
\text { R. Br. }\end{array}$ & PACHNOL & $\begin{array}{l}\text { Hamdard laborato- } \\
\text { ries Waqf Pakistan }\end{array}$ & $\begin{array}{l}\text { Ammonium chloride68.070000 mg/Tab } \\
\text { Calotropis procera (Ait.) R. Br.11.345000 mg/Tab } \\
\text { Ferula assafoetida Linn.5.627000 mg/Tab } \\
\text { Lake salt68.070000 mg/Tab } \\
\text { Myrtus caryophyllus Spreng. } 84.952000 \mathrm{mg} / \mathrm{Tab} \\
\text { Piper nigrum Linn.34.035000 mg/Tab } \\
\text { Potassium Carbonate11.345000 mg/Tab } \\
\text { Sanchal Salt84.952000 mg/Tab } \\
\text { Sodii biboras11.345000 mg/Tab } \\
\text { Zingiber officinale Roscoe 34.035000 mg/Tab }\end{array}$ & Tablet & Twice a day \\
\hline 2 & $\begin{array}{l}\text { Berberis lyceum } \\
\text { Royle }\end{array}$ & AHMAREEN & $\begin{array}{l}\text { QARSHI INDUSTRIES } \\
\quad(P V T) \text { LTD }\end{array}$ & $\begin{array}{l}\text { Ammonium chloride } 30.000000 \mathrm{mg} / 10 \mathrm{ml} \\
\text { Berberis aristata DC. } 200.000000 \mathrm{mg} / 10 \mathrm{ml} \\
\text { Cichorium intybus Linn. } 100.000000 \mathrm{mg} / 10 \mathrm{ml} \\
\text { Citrus limonum Risso (Oil) } 10.000000 \mathrm{mg} / 10 \mathrm{ml} \\
\text { Citrus limonum Risso (Bark) } 300.000000 \mathrm{mg} / 10 \mathrm{ml} \\
\text { Ferrous ammonium sulphate } 50.000000 \mathrm{mg} / 10 \mathrm{ml} \\
\text { Jawahar mohra } 10.000000 \mathrm{mg} / 10 \mathrm{ml} \\
\text { Nelumbium speciosum Willd. } 100.000000 \mathrm{mg} / 10 \mathrm{ml} \\
\text { Rosa damascena Miller } 100.000000 \mathrm{mg} / 10 \mathrm{ml} \\
\text { Santalum album Linn. } 26.660000 \mathrm{mg} / 10 \mathrm{ml} \\
\text { Strychnos nux-vomica Linn. (Extract) } \\
\text { 10.000000 mg/10 ml } \\
\text { Vitis vinifera Linn. } 200.000000 \mathrm{mg} / 10 \mathrm{ml} \\
\text { Preservatives 0.000000 Q.S } \\
\text { Saccharum Base 0.000000 Q.S }\end{array}$ & Syrup & Twice a day \\
\hline 3 & $\begin{array}{c}\text { Achyranthes } \\
\text { aspera L. }\end{array}$ & HOOPINIL & $\begin{array}{l}\text { QARSHI INDUSTRIES } \\
\quad(\text { PVT) LTD }\end{array}$ & $\begin{array}{l}\text { Achyranthes aspera Linn.312.000000 mg/10 ml } \\
\text { Adhatoda vasica Nees } 125.000000 \mathrm{mg} / 10 \mathrm{ml} \\
\text { Ephedra gerardiana Wall. ex } \\
\text { Stapf125.000000 mg/10 ml } \\
\text { Glycyrrhiza glabra Linn. } 125.000000 \mathrm{mg} / 10 \mathrm{ml} \\
\text { Khashkhash musaffa } 125.000000 \mathrm{mg} / 10 \mathrm{ml} \\
\text { Mentha piperita Linn. (Extract) } 2.500000 \mathrm{mg} / 10 \mathrm{ml} \\
\text { Pistacia integerrima J. L. Stewart ex Bran- } \\
\text { dis125.000000 mg/10 ml }\end{array}$ & Syrup & 6 times a day \\
\hline 4 & $\begin{array}{l}\text { Riccinus com- } \\
\text { munis } L \text {. }\end{array}$ & $\begin{array}{l}\text { DAWA-E- } \\
\text { MALISH }\end{array}$ & $\begin{array}{l}\text { Hamdard laborato- } \\
\text { ries Waqf Pakistan }\end{array}$ & $\begin{array}{l}\text { Celastrus paniculatus Willd. (Oil) } 0.500000 \mathrm{~g} / 3 \mathrm{~g} \\
\text { Cinnamomum cassia Blume (Oil) } 0.100000 \mathrm{~g} / 3 \mathrm{~g} \\
\text { Ricinus communis Linn. (Oil) } 1.500000 \mathrm{~g} / 3 \mathrm{~g} \\
\text { Sea Salt0.320000 g/3 g } \\
\text { Styrax benzoin Dryander } 0.160000 \mathrm{~g} / 3 \mathrm{~g} \\
\text { Wax0.320000 g/3 g }\end{array}$ & Liquid & 3 g once daily \\
\hline 5 & $\begin{array}{l}\text { Carthamus } \\
\text { tinctorious L. }\end{array}$ & $\begin{array}{l}\text { NAMAK JALI- } \\
\text { NOOS }\end{array}$ & $\begin{array}{l}\text { Hamdard laborato- } \\
\text { ries Waqf Pakistan }\end{array}$ & $\begin{array}{l}\text { Ammonium chloride } 15.500000 \mathrm{mg} / 500 \mathrm{mg} \text {, } \\
\text { Black salt } 15.500000 \mathrm{mg} / 500 \mathrm{mg} \\
\text { Carthamus tinctorius Linn. } 15.500000 \mathrm{mg} / 500 \mathrm{mg} \\
\text { Carum carvi Linn. } 15.500000 \mathrm{mg} / 500 \mathrm{mg} \\
\text { Cinnamomum cassia Blume } 15.500000 \mathrm{mg} / 500 \mathrm{mg} \\
\text { Cinnamomum malabathrum Batka } \\
15.500000 \mathrm{mg} / 500 \mathrm{mg} \\
\text { Cuminum cyminum Linn. } 15.500000 \mathrm{mg} / 500 \mathrm{mg} \\
\text { Cuscuta reflexa Roxb. } 15.500000 \mathrm{mg} / 500 \mathrm{mg} \\
\text { Foeniculum vulgare Miller } 15.500000 \mathrm{mg} / 500 \mathrm{mg} \\
\text { Lake salt } 30.750000 \mathrm{mg} / 500 \mathrm{mg} \\
\text { Piper nigrum Linn. (White) } 15.500000 \mathrm{mg} / 500 \mathrm{mg} \\
\text { Piper nigrum Linn. (Black) } 15.500000 \mathrm{mg} / 500 \mathrm{mg} \\
\text { Rock Salt } 185.000000 \mathrm{mg} / 500 \mathrm{mg} \\
\text { Valeriana officinalis Linn. } 15.500000 \mathrm{mg} / 500 \mathrm{mg} \\
\text { Zingiber officinale Roscoe } 15.500000 \mathrm{mg} / 500 \mathrm{mg}\end{array}$ & Tablet & 2 tab once daily \\
\hline
\end{tabular}


Table 7 (continued)

\begin{tabular}{|c|c|c|c|c|c|c|}
\hline Sr. no & $\begin{array}{l}\text { Botanical } \\
\text { name }\end{array}$ & Brand name & Manufacturer & Ingredients & Dosage form & Dosage \\
\hline 6 & $\begin{array}{l}\text { Solanum } \\
\text { nigrum L. }\end{array}$ & $\begin{array}{l}\text { MADAMOL } \\
\text { SYRUP }\end{array}$ & $\begin{array}{l}\text { QARSHI INDUSTRIES } \\
\text { (PVT) LTD }\end{array}$ & $\begin{array}{l}\text { Acacia arabica (Lam.) Willd. } 62.500000 \mathrm{mg} / 10 \mathrm{ml} \\
\text { Achillea millefolium Linn. } 62.500000 \mathrm{mg} / 10 \mathrm{ml} \\
\text { Adiantum capillus-veneris Linn } 62.500000 \mathrm{mg} / 10 \mathrm{ml} \\
\text { Cichorium endivia Linn. } 62.500000 \mathrm{mg} / 10 \mathrm{ml} \\
\text { Ficus bengalensis Linn. } 62.500000 \mathrm{mg} / 10 \mathrm{ml} \\
\text { Fumaria offcinalis } 62.500000 \mathrm{mg} / 10 \mathrm{ml} \\
\text { Gendarussa vulgaris } 62.500000 \mathrm{mg} / 10 \mathrm{ml} \\
\text { Iron Compound } 50.000000 \mathrm{mg} / 10 \mathrm{ml} \\
\text { Juniperus communis Linn. var. saxatilis Pall. } \\
\text { 62.500000 mg/10 ml } \\
\text { Melia azadarach Linn. } 62.500000 \mathrm{mg} / 10 \mathrm{ml} \\
\text { Nepeta ruderalis Ham. } 62.500000 \mathrm{mg} / 10 \mathrm{ml} \\
\text { Pimpinella anisum Linn. } 62.500000 \mathrm{mg} / 10 \mathrm{ml} \\
\text { Rubia cordifolia Linn. } 62.500000 \mathrm{mg} / 10 \mathrm{ml} \\
\text { Solanum nigrum Linn. } 62.500000 \mathrm{mg} / 10 \mathrm{ml}\end{array}$ & Syrup & $\begin{array}{l}2 \text { teaspoon } \\
\text { twice a day }\end{array}$ \\
\hline 7 & $\begin{array}{l}\text { Aloe barbaden- } \\
\text { sis Mill. }\end{array}$ & BARRISAL & $\begin{array}{l}\text { Hamdard laborato- } \\
\text { ries Waqf Pakistan }\end{array}$ & Aloe barbadensis Mill. $1.000000 \mathrm{~g} / 100 \mathrm{ml}$ & Syrup & $\begin{array}{l}5 \text { teaspoon } \\
\text { thrice a day }\end{array}$ \\
\hline 8 & $\begin{array}{l}\text { Ficus carica } \\
\text { Linn. }\end{array}$ & $\begin{array}{l}\text { BERSEENA } \\
\text { QURS }\end{array}$ & $\begin{array}{l}\text { Hamdard laborato- } \\
\text { ries Waqf Pakistan }\end{array}$ & $\begin{array}{l}\text { Acacia arabica (Lam.) Willd. } 23.520000 \mathrm{mg} / \mathrm{Tab} \\
\text { Ficus caricaLinn. } 23.520000 \mathrm{mg} / \mathrm{Tab} \\
\text { Melia azadarach Linn. (Peel) } 23.520000 \mathrm{mg} / \mathrm{Tab} \\
\text { Melia azadirachta Linn (Leaves) } 23.520000 \mathrm{mg} / \mathrm{Tab} \\
\text { Melia azadirachta Linn (Bark) } 23.520000 \mathrm{mg} / \mathrm{Tab} \\
\text { Psoralea corylifolia Linn. } 23.520000 \mathrm{mg} / \mathrm{Tab}\end{array}$ & Tablet & $\begin{array}{l}3 \text { tab thrice a } \\
\text { day }\end{array}$ \\
\hline 9 & $\begin{array}{l}\text { Fumaria indica } \\
\text { Linn }\end{array}$ & $\begin{array}{l}\text { ITRIFAL SHAH- } \\
\text { HATRA }\end{array}$ & $\begin{array}{l}\text { Hamdard laborato- } \\
\text { ries Waqf Pakistan }\end{array}$ & $\begin{array}{l}\text { Cassia angustifolia Vahl. } 0.075000 \mathrm{~g} / 6 \mathrm{~g} \\
\text { Emblica officinalis Linn. (Dry) } 0.150000 \mathrm{~g} / 6 \mathrm{~g} \\
\text { Fumaria indica (Haussk) Pugsley (Leaves) } \\
\quad 0.375000 \mathrm{~g} / 6 \mathrm{~g} \\
\text { Rosa damascene Miller } 0.045000 \mathrm{~g} / 6 \mathrm{~g} \\
\text { Terminalia chebula Retz. } 0.150000 \mathrm{~g} / 6 \mathrm{~g} \\
\text { Sweetening agent and preservatives } 0.000000 \text { Q.S }\end{array}$ & Semi solid & 6-12 g daily \\
\hline
\end{tabular}

with unregulated harvesting and tapping of oleo-gum resin. This species is therefore assessed as Critically Endangered [52]. Soni identified a number of relevant activities within the study area under the theme 'Guggal Bachao Abhiyan' (Save Guggal Movement). These were conducted through the close co-operation of the village level communities, who depend on local biodiversity for their livelihoods in the Aravali Hills of Rajasthan [53].

Gentiana kurroo is mainly collected from the wild and there is no information regarding its cultivation.
Hence, the species is under severe threat of extinction. This assessment was primarily based on the very limited reported presence of the species in wild and the high demand and prices for the dried roots of this plant. The wild population in IndoPak region is inferred to have declined by $80 \%$ in a 10 years time period. The recent CAMP assessment also agrees with the trend of population decline of more than $80 \%$ in India. Therefore, the species is assessed as Critically Endangered [54, 55]. 


\section{Commercially available important plants}

Plants that are available commercially in Pakistan in different formulations are enlisted in Table 7.

Worth and number of herbal industries is increasing day by day in Pakistan due to the trust of people on traditional medicines [56].

Ethno-medicines has a vital role in the industrialization [57]. Vivienne et al. stated commercial importance of medicinal plants in South Africa and reported 11 species of medicinal plants that are imported from India and other countries including Cinnamommum camphora. They also concluded that the size of the regional market of medicinal plants can be assessed by knowing the number of species traded. Commercial utilization of the medicinal plant is directly related to the degree of extinction [45].

\section{Future considerations}

The review revealed that many of the important information like ethno preparation, habit and part used, of many important medicinal plants were not available in previous articles which can be due to the lack of interest of local youth to acquire the traditional knowledge from the ancestors and thus provision of incomplete information to the previous articles, further ethno-pharmacological research should be carried out to save the traditional knowledge and to take it to the light of science.

Medicinal plants in Pakistan contain great variety which can be used against a large number of skin ailments. Leaves, whole plant and roots are the most widely used parts in different ethno-medicinal preparations. Whole plant and root harvesting are the destructive type of techniques, it is important to protect the medicinal plants from exploitation. Although in Pakistan there is a strong traditional background supporting the use of these ethno-medicines against skin ailments but detailed ethno-pharmacological studies are not enough to support the folk claim. Majority of the studies have not documented other information regarding mode of preparation and dose of ethno-medicine. Therefore it is necessary to carry out a comprehensive study on ethno-pharmacology in Pakistan. It is important as the folk knowledge supplements a scientific investigations and penetrations with the primary information. Very limited number of studies provides toxic profile of these medicinal plants, toxicity studies should be carried out for these medicinal plants in animal system to establish a safe dose range.

More pharmacological studies (in vitro and in vivo) should be carried out on medicinal plants of Pakistan that are relatively unexplored or less explored. Mostly, the extracts were tested against different pathogens, for wound healing properties and for other skin conditions. However, very few classes of secondary metabolites and pure isolated components were tested. Therefore, it is imperative to conduct detailed phytochemical studies for the isolation of novel compounds.

\section{Authors' contributions}

A gave basic concept of the paper and reviewed and drafted the manuscript, AS, HA, WY, HR, also collected and analyzed data and drafted the manuscript. $I A B$ and $A M A$ collected papers using facilities of their university and also helped in writing paper. All authors read and approved the final manuscript.

\section{Author details \\ ${ }^{1}$ Laboratory of Cardiovascular Research and Integrative Pharmacology, Col- lege of Pharmacy, University of Sargodha, Sargodha, Pakistan. ${ }^{2}$ Rashid Latif College of Pharmacy, Lahore, Pakistan. ${ }^{3}$ Department of Pharmacology, Col- lege of Medicine, King Saud University Riyadh, Riyadh, Saudi Arabia. ${ }^{4}$ Prince Abdullah Ben Khaled Celiac Disease Research Chair, Department of Pediatrics, Faculty of Medicine, King Saud University, Riyadh, Saudi Arabia.}

\section{Acknowledgements}

The authors extend their appreciation to the deanship scientific research at King Saud university for funding this research through \# (RG-1439-002).

\section{Competing interests}

The authors declare that they have no competing interests.

\section{Availability of data and materials}

All data generated and analyzed in this study is has been taken from the free excess sources while those which were not available online were taken by authors from king Saud University.

Consent for publication

Not applicable.

Ethics approval and consent to participate Not applicable.

\section{Funding}

Not applicable.

\section{Publisher's Note}

Springer Nature remains neutral with regard to jurisdictional claims in published maps and institutional affiliations.

Received: 13 May 2018 Accepted: 11 October 2018

Published online: 19 October 2018

References

1. Musharaf K. Ethnobotanical studies on plant resources of Sheikh Maltoon, District Mardan, Pakistan. J Med Plants Res. 2014;4(5):35-45.

2. Maroyi A. Traditional use of medicinal plants in south-central Zimbabwe : review and perspectives. J Ethnobiol Ethnomed. 2013;9:31.

3. Ahmad M, Sultana S, Fazl-I-Hadi S, Ben Hadda T, Rashid S, Zafar M, Khan MA, Khan M, Yaseen G. An ethnobotanical study of medicinal plants in high mountainous region of Chail valley (District Swat-Pakistan). J Ethnibiol Ethnomed. 2014;10(1):36.

4. Abbasi AM, Khan MA, Shah MH, Shah MM, Pervez A, Ahmad M. Ethnobotanical appraisal and cultural values of medicinally important wild edible vegetables of Lesser Himalayas-Pakistan. J Ethnibiol Ethnomed. 2013;9(1):66.

5. Bin Asad HHM, Murtaza G, Siraj S, Khan AS, Azhar S, Hussain SM, Ismail T, Hussain SM, Hussain I. Enlisting the scientifically unnoticed medicinal plants of Pakistan as a source of novel therapeutic agents showing antivenom activity. Afr J Pharm Pharmacol. 2011;5(20):2292-305. 
6. Mussarat S, Abdel-Salam NM, Tariq A, Wazir SM, Ullah R, Adnan M. Use of ethnomedicinal plants by the people living around indus river. Evid Based Complement Alternat Med. 2014;2014:212634.

7. Khan AS, Hassan M, Ali S. Secondary metabolite studies of some selected plants of District Gilgit, Gilgit-Baltistan. Int J Pharmacog Phytochem Res. 2014;6(3):467-71.

8. Ahmad SS, Erum S, Khan MS, Nawaz M, Abdul W. Exploring the medicinal plants wealth: a traditional medico-botanical knowledge of local communities in Changa Manga Forest, Pakistan. Middle-East J. 2014;20(12):1772-9.

9. Manzoor M, Durrani J, Ayesha A. Uses of fruits, vegetables and herbs for the treatment of diabetes by the people of Quetta city. Sci Tech Dev. 2013:32(1):24-7.

10. Johnsy G, Sargunam SD, Kaviyarasan V. Indigenous knowledge of medicinal plants used for the treatment of skin diseases by the Kaani tribe of Kanyakumari District. Int Pharm Pharmaceut Sci. 2012;4(1):309-13.

11. Ali H, Qaiser M. The ethnobotany of chitral valley. Pakistan with particular reference to medicinal plants. Pak J Bot. 2009;41(4):2009-41.

12. Bibi T, Ahmad M, Tareen BR, Tareen MN, Jabeen R, Ur-Rehman S, Sultana S, Zafar M, Yaseen G. Ethnobotany of medicinal plants in district Mastung of Balochistan province-Pakistan. J Ethnopharmacol. 2014;157:79-89.

13. Arshad M, Ahmad M, Ahmed E, Saboor A, Abbas A, Sadiq S. An ethnobiological study in Kala Chitta hills of Pothwar region. Pakistan: multinomial logit specification. J Ethnobiol Ethnomed. 2014;10:13.

14. Gilani SA, Khan AM, Qureshi RA, Sherwani SK, Rehman RU, Bukhari TZ. Advances in bioresearch ethno-medicinal treatment of common gastrointestinal disorders by indigenous people in Pakistan. Adv Biores. 2014;5(1):42-9.

15. Shinwari KZ. Medicinal plants research in Pakistan. J Med Plants Res. 2010;4(3):161-76.

16. Ahmed JM, Malik HZ, Khan S, Nasar S. Biological spectrum and ethnomedicinal uses of plants in Chellah district Muzaffarabad Azad Kashmir Pakistan. J Adv Bot Zool. 2014;1 (4):1-5.

17. Shedayi AA, Gulshan B. Ethnomedicinal uses of plant resources in GilgitBaltistan of Pakistan. J Med Plants Res. 2012;6(29):4540-9.

18. Shaheen H, Nazir J, Firdous SS, Khalid A. Cosmetic ethnobotany practiced by tribal women of Kashmir Himalayas. Avicenna J Phytomed. 2014;4(4):239-50.

19. Hussain S, Malik F, Riaz H, Qayyum MA, Khalid N. Alternative and traditional medicines systems in Pakistan: history, regulation, trends, usefulness, challenges, prospects and limitations. New York: INTECH Open Access Publisher; 2012.

20. Baloch PM, Marri MY, Qaisrani MA, Baloch A. Plants treasures, traditional knowledge and baloch society. Bi Ann Res J. 2013;28(1):1810-2174.

21. Bano A, Ahmad M, Zafar M, Sultana S, Rashid S, Khan MA. Ethnomedicinal knowledge of the most commonly used plants from Deosai Plateau, Western Himalayas, Gilgit Baltistan, Pakistan. J Ethnopharmacol. 2014;155:1046-52.

22. Ahmad SK, Habib S. Indigenous knowledge of some medicinal plants of himalaya region, Dawarian Village, Neelum Valley, Azad Jammu and Kashmir, Pakistan. Univ J Plant Sci. 2014;2(2):40-7.

23. Hostettmann K, Marston A, Ndjoko Loset K, Wolfender JL. The potential of African plants as a source of drugs. Curr Org Chem. 2000;4(10):973-1010.

24. Dawid-Pać R. Medicinal plants used in treatment of inflammatory skin diseases. Postepy Dermatol Alergol. 2013;30(3):170-7.

25. De Wet H, Nkwanyana MN, van Vuuren SF. Medicinal plants used for the treatment of diarrhoea in northern Maputaland, KwaZulu-Natal Province, South Africa. J Ethnopharmacol. 2010;130(2):284-9.

26. Njoroge GN, Bussmann RW. Ethnotherapeautic management of skin diseases among the Kikuyus of Central Kenya. J Ethnopharmacol. 2007:111(2):303-7.

27. Doğan A, Demirci S, Cağlayan AB, Kilıç E, Günal MY, Uslu U, Cumbul A, Sahin F. Sodium pentaborate pentahydrate and pluronic containing hydrogel increases cutaneous wound healing in vitro and in vivo. Biol Trace Elem Res. 2014;7(3):37-44.

28. Tabassum N, Hamdani M. Plants used to treat skin diseases. Pharmacogn rev. 2014;8(15):52.
29. Tariq A, Musarat S, Adnan M. Review on ethno medicinal, phytochemical and pharmacological evidence of Himalayan anticancer plants. J Ethnopharmacol. 2015;164:96-119.

30. Kumar K, Sharma YP, Manhas RK, Bhatia H. Ethnomedicinal plants of Shankaracharya Hill, Srinagar, J\&K, India. J Ethnopharmacol. 2015;170:255-74.

31. Barker MS, Kane NC, Matvienko M, Kozik A, Michelmore RW, Knapp SJ, Rieseberg LH. Multiple paleopolyploidizations during the evolution of the Compositae reveal parallel patterns of duplicate gene retention after millions of years. Mol Biol Evol. 2008;25(11):2445-55.

32. Kumar S, Malhotra R, Kumar D. Euphorbia hirta: its chemistry, traditional and medicinal uses, and pharmacological activities. Pharmacogn Rev. 2010:4(7):58-61.

33. Saikia AP, Ryakala VK, Sharma P, Goswami P, Bora U. Ethnobotany of medicinal plants used by Assamese people for various skin ailments and cosmetics. J Ethnopharmacol. 2006;106(2):149-57.

34. Mabona U, Van Vuuren FS. Southern African medicinal plants used to treat skin diseases. S Afr J Bot. 2013;87:175-93.

35. Khan SM, Page S, Ahmad H, Harper D. Identifying plant species and communities across environmental gradients in the Western Himalayas: method development and conservation use. Ecol Inf. 2013;14:99-103.

36. Ahmad M, Qureshi R, Arshad M, Khan MA, Zafar M. Traditional herbal remedies used for the treatment of diabetes from district Attock (Pakistan). Pak J Bot. 2009;41 (6):2777-82.

37. Bhat JA, Kumar M, Bussmann RW. Ecological status and traditional knowledge of medicinal plants in Kedarnath Wildlife Sanctuary of Garhwal Himalaya, India. J Ethnobiol Ethnomed. 2013:9:1.

38. Ghorbani A. Studies on pharmaceutical ethnobotany in the region of Turkmen Sahra, north of Iran:(part 1): general results. J Ethnopharmacol. 2005;102(1):58-68.

39. Ayyanar $\mathrm{M}$, Ignacimuthu $\mathrm{S}$. Ethnobotanical survey of medicinal plants commonly used by Kani tribals in Tirunelveli hills of Western Ghats, India. J Ethnopharmacol. 2011;134:851-64.

40. Adnan M, Ullah I, Tariq A, Murad W, Azizullah A, Khan AL, Ali N. Ethnomedicine use in the war affected region of northwest Pakistan. J Ethnobiol Ethnomed. 2014;10:1-16.

41. Farnsworth NR. The role of ethnopharmacology in drug development. In: Chadwick DJ, Marsh J, editors. Bioactive compounds from plants Ciba-Geigy Symposium No154 Bangkok 20-22February. Wiley: New York; 1990. p. 2-21.

42. Watt JM, Breyer-Brandwijk MG. The medicinal and poisonous plants of southern and eastern Africa. 2nd ed. London: Livingstone Edinburgh: 1962. p. 205-6.

43. Hutchings A. Zulu medicinal plants: an inventory. Kwazulu: University of Kwazulu Natal Press; 1996

44. Felhaber T. South African traditional healers' primary health care handbook, Kagiso Publishers. South Africa: Cape Town; 1997.

45. Williams VL, Balkwill K, Witkowski ET. Unraveling the commercial market for medicinal plants and plant parts on the Witwatersrand, South Africa. Econ Bot. 2000;54(3):310-27.

46. Bhatt D, Joshi GC, Kumar R, Tewari LM. Phytosociological features and threat categorization of $A$ heterophyllum Wall. ex. Royle and A. ferox Wall ex. Ser in Kumaun. J Ecol Nat Environ. 2014:6(3):111-8.

47. Ved DK, Kinhal GA, Ravikumar K, Prabhakaran V, Ghate U, Sankar RV, Indresha JH. Conservation assessment \& management prioritisation for the medicinal plants of Jammu \& Kashmir. Himachal Pradesh: Foundation for Revitalisation of Local Health Traditions; 2003.

48. Ved DK, Kinhal GA, Ravikumar K, Sankar RV, Haridasan K. Conservation Assessment and Management Prioritisation (CAMP) for wild medicinal plants of North-East India. Med Plant Conserv. 2005;11:40-4.

49. Belt J, Lengkeek A, VanderZant J. Cultivating a healthy enterprise: developing a sustainable medicinal plant chain in Uttaranchal-India. Amsterdam: KIT Publishers; 2003. p. 350.

50. Srivastava N, Sharma V, Kamal B, Jadon VS. Aconitum: need for sustainable exploitation (with special reference to Uttarakhand). Int J Green Pharm. 2010:4:220-8.

51. Soni V. Conservation of Commiphora wightii, an endangered medicinal shrub, through propagation and planting, and education awareness programs in the Aravali Hills of Rajasthan, India. Cons Eviron. 2010;7(2):27-31. 
52. Goraya GS, Jishtu V, Rawat GS, Ved DK. Wild medicinal plants of Himachal Pradesh: an assessment of their conservation status and management prioritisation. Shimla: Himachal Pradesh Forest Department; 2013.

53. Singh SK, Rawat GS. Flora of Great Himalayan National Park: Himachal Pradesh; 2000.

54. Shinwari ZK, Watanabe T, Rehman M, Youshikawa T. A Pictorial Guide to medicinal plants of Pakistan. Kohat: Kohat University of Science and Technology; 2006

55. Cano HJ, Volpado G. Herbal mixtures in the traditional medicines of eastern Cuba. J Ethnopharmacol. 2004;90:293-316.

56. Haq F, Ahmad H, Alam M. Traditional uses of medicinal plants of Nandiar Khuwarr catchment (District Battagram), Pakistan. J Med Plants Res. 2011;5(1):39-48.

57. Arshad M, Nisar FM, Majeed A, Ismail S, Ahmad M. Ethno medicinal flora in District Sialkot, Punjab, Pakistan. Middle-East J Sci Res. 2011;9(2):209-14.

58. Kamal M, Wazir SM, Hassan M, Subhan M, Khan SU, Muhammad M, Taj S. Ethnobotanically important plants of district Bannu, Pakistan. Pak J Plant Sci. 2009;15(2):87-93.

59. Qureshi RM, Maqsood M, Arshad M, Chaudhry AK. Ethnomedicinal uses of plants by the people of Kadhi areas of Khushab, Punjab, Pakistan. Pak J Bot. 2011;43(1):121-33.

60. Ishtiaq M, Mumtaz SA, Hussain T, Ghani A. Medicinal plant diversity in the flora of Leepa Valley, Muzaffarabad (AJK), Pakistan. Afr J Biotechnol. 2012;11(13):3087-98.

61. Imtiaz S, Abdullah S, Afzal S, Rehman G, Waheed M. Medicinal plants used by traditional healers of Punjab, Pakistan. Can J App Sci. 2013;3(4):496-515.

62. Begum S, Abdeislam NM, Adnan M, Tariq A, Yasmin A, Hameed R. Ethnomedicines of highly utilized plants in the temperate himalayan region. Afr J Tradit Complement Altern Med. 2014;11(3):132-42.

63. Mahmood A, Mahmood A, Mujtaba G, Mumtaz MS, Kayani WK, Khan MA. Indigenous medicinal knowledge of common plants from district Kotli Azad Jammu and Kashmir Pakistan. J Med Plant Res. 2012;6:4961-7.

64. Abbasi AM, Khan MA, Ahmed M, Zafar M. Herbal medicines used to cure various ailments by the inhabitants of Abbottabad district, North West Frontier Province, Pakistan. Indian J Trad Know. 2010;9(1):175-83.

65. Sabeen M, Ahmad DSS. Exploring the folk medicinal flora of Abbotabad City, Pakistan. Ethnobotl Leaflets. 2009;13:810-33.

66. Rauf F, Qureshi R, Shaheen H. Folk medicinal uses of indigenous plant species of Barroha, Bhara Kahu and Maanga in Islamabad, Pakistan. J Med Plant Res. 2012;6(11):2061-70.

67. Hussain K, Nisar FM, Majeed A, Nawaz K, Bhatti HK. Ethnomedicinal survey for important plants of Jalalpur Jattan, District Gujrat, Punjab, Pakistan. Ethnobot Leaflets. 2010;14:807-25.

68. Naz I, Ahmad M, Ul-Hassan T. Ethnobotanical investigation of medicinal flora used by indigenous People in District Attock, Pakistan. J Adv Bot Zool. 2014;1(4):1-7.

69. Ahmad M, Khan AM, Manzoor S, Zafar M, Sultana S. Check list of medicinal flora of Tehsil Isakhel, District Mianwali-Pakistan. Ethnobot Leaflets. 2006:10:41-8.

70. Ghani A, Ali Z, Perveen S. Folk recipes and ethno botanical survey of medicinal plants Mianwali district (Pakistan). Int J Curr Pharm Res. 2012;4(2):61-3.

71. Panhwar QA, Abro H. Ethnobotanical studies of Mahal Kohistan (Khirthar national park). Pak J Bot. 2009;39(7):2301-15.

72. Mahmood A, Mahmood A, Shaheen H, Qureshi RA, Sangi Y, Gilani SA. Ethno medicinal survey of plants from district Bhimber Azad Jammu and Kashmir, Pakistan. J Med Plant Res. 2011;5(11):2348-60.

73. Jabeen A, Khan MA, Ahmad M, Zafar M, Ahmad F. Indigenous uses of economically important flora of Margallah hills national park, Islamabad, Pakistan. Afr J Biotechnol. 2009;8(5):763-84.

74. Mahmood A, Mahmood A, Malik RN. Indigenous knowledge of medicinal plants from Leepa valley, Azad Jammu and Kashmir, Pakistan. J Ethnopharmacol. 2012;143(1):338-46.

75. Nisar MF, Jaleel F, Haider SM, Toor Y, Ismail S, Arfan M, Azeem M. Exploration of ethno-medicinal plants and their ritual uses in Bahawalnagar, Pakistan. Middle-East J Sci Res. 2014;21(9):1466-71.
76. Shedayi AA, Xu M, Gulraiz B. Traditional medicinal uses of plants in Gilgit-Baltistan, Pakistan. J Med Plants Res. 2014;8(30):992-1004.

77. Khan N, Ahmed M, Ahmed A, Shaukat SS, Wahab M, Ajaib M, Siddiqui FM, Nasir M. Important medicinal plants of Chitral Gol National Park (CGNP) Pakistan. Pak J Bot. 2011;43(2):797-809.

78. Parvaiz M, Bhatti KH, Nawaz K, Hussain Z, Khan RMW, Hussain A. Ethno-botanical studies of medicinal plants of Dinga, District Gujrat, Punjab, Pakistan. World Appl Sci J. 2013;26(6):826-33.

79. Husain SZ, Malik RN, Javaid M, Bibi S. Ethonobotanical properties and uses of medicinal plants of Morgah biodiversity park, Rawalpindi. Pak J Bot. 2008;40(5):1897-911.

80. Awan AA, Murtaza G. Ethnobotanical uses of plants of family Solanaceae muzaffarabad division Azad Jammu and Kashmir, Pakistan-13100. Int Pharm Sci Invention. 2013;2(7):5-11.

81. Shah A, Marwat KS, Gohar F, Khan A, Bhatti HK, Amin M, Ud-Din N, Ahmad M, Zafar M. Ethnobotanical study of medicinal plants of semi-tribal area of Makerwal \& Gulla Khel (lying between Khyber Pakhtunkhwa and Punjab Provinces), Pakistan. Am J Plant Sci. 2013;4:98-116.

82. Jan G, Khan MA, Gul F. Ethnomedicinal plants used against diarrhea and dysentery in Dir Kohistan valley (NWFP), Pakistan. Ethnobot Leaflets. 2008;12:620-37.

83. Khan B, Abdukadir A, Qureshi R, Mustafa G. Medicinal uses of plants by the inhabitants of Khunjerab National Park, Gilgit, Pakistan. Pak J Bot. 2011:43(5):2301-10.

84. Afzal S, Afzal N, Awan RM, Khan ST, Gilani A, Khanum R, Tariq S. Ethno-botanical studies from Northern Pakistan. J Ayub Med Coll Abbottabad. 2009;21(1):52-7.

85. Sarangzai MA, Ahmed A, Laghari KS. Traditional uses of some useful medicinal plants of Ziarat district Balochistan, Pakistan. FUUAST J Biol. 2013;3(1):101-7.

86. Patil RA, Makwana AB. Anti-hyperbilirubinemic and wound healing activity of aqueous extract of Calotropis procera leaves in Wistar rats. Ind J Pharmacol. 2015;47(4):398.

87. Qaiser Joshi AL, Roham PH, Mhaske R, Jadhav M, Krishnadas K, Kharat A, Hardikar B, Kharat KR. Calotropis procera extract induces apoptosis and cell cycle arrest at G2/M phase in human skin melanoma (SKMEL-2) cells. Nat Prod Res. 2015;29(23):2261-4.

88. Aderounmu AO, Omonisi AE, Akingbasote JA, Makanjuola M, Bejide RA, Orafidiya LO, Adelusola KA. Wound-healing and potential anti-keloidal properties of the latex of Calotropis procera (Aiton) Asclepiadaceae in rabbits. Afr J Tradit Complement Altern Med. 2013;10(3):574-9.

89. Laitiff AA, Teoh SL, Das S. Wound healing in diabetes mellitus: traditional treatment modalities. Clin Ter. 2010;161(4):359-64.

90. Rasik AM, Raghubir R, Gupta A, Shukla A, Dubey PM, Srivastava S, Jain $\mathrm{KH}$, Kulshrestha KD. Healing potential of Calotropis procera on dermal wounds in Guinea pigs. J Ethnopharmacol. 1999;68(1-3):261-6.

91. Asif A, Kakub G, Mehmood S, Khunum R, Gulfraz M. Wound healing activity of root extracts of Berberis lyceum royle in rats. Phytother Res. 2007;21(6):589-91.

92. Pirzada AJ, Shaikh W, Usmanghani K, Mohiuddin E. Antifungal activity of Dodonaea viscosa Jacq extract on pathogenic fungi isolated from superficial skin infection. Pak J Pharm Sci. 2010;23(3):337-40.

93. Teshome K, Gebre-Mariam T, Asres K, Engidawork E. Toxicity studies on dermal application of plant extract of Dodonaea viscosa used in Ethiopian traditional medicine. Phytother Res. 2010;24(1):60-9.

94. Patel M, Coogan MM, Teshome K, Gebre-Mariam T, Asres K, Engidawork E. Antifungal activity of the plant Dodonaea viscosa var. angustifolia on Candida albicans from HIV-infected patients. J Ethnopharmacol. 2008;118(1):173-6.

95. Chakraborty A, Brantner A, Mukainaka T, Nobukuni Y, Kuchide M, Konoshima T, Tokuda H, Nishino H. Cancer chemopreventive activity of Achyranthes aspera leaves on Epstein-Barr virus activation and twostage mouse skin carcinogenesis. Cancer Lett. 2002;177(1):1-5.

96. Taye B, Giday M, Animut A, Seid J. Antibacterial activities of selected medicinal plants in traditional treatment of human wounds in Ethiopia. Asian Pac J Trop Biomed. 2011;1(5):370-5.

97. Barua CC, Talukdar A, Begum SA, Pathak DC, Sarma DK, Borah RS, Gupta A. In vivo wound-healing efficacy and antioxidant activity of Achyranthes aspera in experimental burns. Pharm Biol. 2012;50(7):892-9. 
98. Fikru A, Makonnen E, Eguale T, Debella A, Abie Mekonnen G. Evaluation of in vivo wound healing activity of methanol extract of Achyranthes aspera L. J Ethnopharmacol. 2012;143(2):469-74.

99. Mukherjee H, Ojha D, Bag P, Chandel HS, Bhattacharyya S, Chatterjee TK, Mukherjee PK, Chakraborti S, Chattopadhyay D. Anti-herpes virus activities of Achyranthes aspera: an indian ethnomedicine, and its triterpene acid. Microbiol Res. 2013;168(4):238-44.

100. Gangopadhyay KS, Khan M, Pandit S, Chakrabarti S, Mondal TK, Biswas TK. Pharmacological evaluation and chemical standardization of an ayurvedic formulation for wound healing activity. Int J Low Extrem Wounds. 2014;13(1):41-9.

101. Benson KF, Newman RA, Jensen GS. Antioxidant, anti-inflammatory, anti-apoptotic, and skin regenerative properties of an Aloe vera-based extract of Nerium oleander leaves $\left(\right.$ nae- $\left.8\left({ }^{\circledR}\right)\right)$. Clin Cosmet Investig Dermatol. 2015;8:239-48.

102. Ajose FO. Some Nigerian plants of dermatologic importance. Int J Dermatol. 2007;1:48-55.

103. Ali-Shtayeh MS, Al-Assali AA, Jamous RM. Antimicrobial activity of Palestinian medicinal plants against acne-inducing bacteria. Univ J Microbiol Res. 2013;7(21):2560-73.

104. Nemudzivhadi V, Masoko P. In vitro assessment of cytotoxicity, antioxidant, and anti-inflammatory activities of ricinus communis (Euphorbiaceae) leaf extracts. Evid Based Complement Altern Med. 2014;2014:625961.

105. Martínez GJ, Barboza GE. Natural pharmacopoeia used in traditional Toba medicine for the treatment of parasitosis and skin disorders (Central Chaco, Argentina). J Ethnopharmacol. 2010;132(1):86-100.

106. Lomash V, Parihar SK, Jain NK, Katiyar AK. Effect of Solanum nigrum and Ricinus communis extracts on histamine and carrageenan-induced inflammation in the chicken skin. Cell Mol Biol. 2010;9:56.

107. Roh JS, Han JY, Kim JH, Hwang JK. Inhibitory effects of active compounds isolated from safflower (Carthamus tinctorius L.) seeds for melanogenesis. BiolPharm Bull. 2004:27(12):1976-8.

108. Chen YS, Lee SM, Lin CC, Liu CY, Wu MC, Shi WL. Kinetic study on the tyrosinase and melanin formation inhibitory activities of carthamus yellow isolated from Carthamus tinctorius L. J Biosci Bioeng 2013;115(3):242-5.

109. Kong SZ, Shi XG, Feng XX, Li WJ, Liu WH, Chen ZW, Xie JH, Lai XP, Zhang SX, Zhang XJ, Su ZR. Inhibitory effect of hydroxysafflor yellow on mouse skin photoaging induced by ultraviolet irradiation. Rejuvenation Res. 2013;16(5):404-13.

110. Joshi A, Sengar N, Prasad SK, Goel RK, Singh A, Hemalatha S. Woundhealing potential of the root extract of Albizzia lebbeck. Planta Med. 2013;79(9):737-43.

111. Kováč I, Ďurkáč J, Hollý M, Jakubčová K, Perželová V, Mučaji P, Smetana K. Plantago lanceolata $\mathrm{L}$. water extract induces transition of fibroblasts into myofibroblasts and increases tensile strength of healing skin wounds. J Pharm Pharmacol. 2015:67(1):117-25.

112. Sultana S, Khan AM, Ahmad M, Zafar M. Indigenous knowledge of folk herbal medicines by the women of District Chakwal, Pakistan. Ethnobot Leaflets. 2006;10:243-53.

113. Qureshi R, Bhatti GR, Memon RA. Ethnomedicinal uses of herbs from northern part of Nara desert, Pakistan. Pak J Bot. 2010;42(2):839-51.

114. Ishtiaq M. Medicinal plant diversity in the flora of Leepa Valley, Muzaffarabad (AJK). Pakistan. Afr J Biotechnol. 2012;11(12):2087-98.

115. Alam P, Ali M. Phytochemical investigation of Calotropis procera Ait roots. CSIR. 2009:48B(03):443-6.

116. Sabir S, Tahir K, Rashid N, Naz S, Masood B, Shah MA, Sualeh M. Phytochemical and antioxidant studies of Berberis lycium. Pak J Pharm Sci. 2013;26(6):1165-72.

117. Rani MS, Pippalla RS, Mohan K. Dodonaea viscosa Linn._-an overview. Asian J Pharm Res Health Care. 2009;1 (1):97-112.

118. Srivastav S, Singh P, Mishra G, Jha KK, Khosa RL. Achyranthes asperan important medicinal plant: a review. J Nat Prod Plant Resour. 2011;1(1):1-14.

119. Derwich E, Benziane Z, Boukir A. Antibacterial activity and chemical composition of the essential oil from flowers of Nerium oleander. Electronic J Environ Agric Food Chem. 2010;9:6

120. Jena J, Gupta AK. Ricinus communis Linn: a phytopharmacological review. Int J Pharm Pharm Sci. 2012;4(4):25-9.
121. Zhou YZ, Chen H, Qiao L, Hao DF, Hua HM, Pei YH. Chemical constituents from Carthamus tinctorius L. Chinese J Med Chem. 2007;17(6):380.

122. Zhao Y, Liu F, Lou HX. Studies on the chemical constituents of Solanum nigrum. J Chin Med Mater. 2010;33(4):555-6.

123. Kokila K, Priyadharshini SD, Sujatha V. Phytopharmacological properties of Albizia species: a review. Int J Pharm Pharm Sci. 2013;5(3):70-3.

124. Tamura Y, Nishibe $S$. Changes in the concentrations of bioactive compounds in plantain leaves. J Agric Food Chem. 2002;50(9):2514-8.

125. Kavishankar GB, Lakshmidevi N, Murthy SM, Prakash HS, Niranjana SR. Diabetes and medicinal plants - a review. Int J Pharm Biomed Sci. 2011;2(3):65-80.

126. Ahmed N, Mahmood A, Mahmood A, Tahir SS, Bano A, Malik NR, Hassan S, Ishtiaq M. Relative importance of indigenous medicinal plants from Layyah district, Punjab Province, Pakistan. J Ethnopharmacol. 2014;155(1):509-23.

127. Shinwari KZ, Gilani SS. Sustainable harvest of medicinal plants at Bulashbar Nullah, Astore (Northern Pakistan). J Ethnopharmacol. 2003;84:289-98.

128. Hussain I, Bano A, Ullah F. Traditional drug therapies from various medicinal plants of Central Karakoram National Park. Pak J Bot. 2011:43:79-84.

129. Marwat KS, Khan AM, Ahmad M, Zafar M, Ur-Rehman F. Ethnophytomedicines for treatment of various diseases in DI, Khan District. J Agric. 2008;24(2):305-16.

130. Hamayun M, Khan A, Afzal S, Khan MA. Study on traditional knowledge and utility of medicinal herbs of district Buner, NWFP, Pakistan. Indian J Trad Know. 2006;5(3):407-12.

131. Ghani A, Batool M. Folk recipes of some medicinal plants used by the inhabitants of soon valley khushab (Pakistan). Int J Curr Pharm Res. 2012:4(1):60-3.

132. Marwat KS, Ur-Rehman F, Usman K, Khakwani AA, Ghulam S, Anwar N, Sadiq M, Khan JS. Medico-ethnobotanical studies of edible wild fruit plants species from the flora of north western Pakistan (D. I. Khan district). J Med Plants Res. 2011;5(16):3679-86.

133. Ajaib M, Ud-Din Khan Z. Ethnobotanical studies of useful trees of District Kotli, Azad Jammu and Kashmir. Biologia. 2014;60(1):63-71.

134. Khan K, Erum A, Ahmad B, Akram M, Anwar M, Junaid A, Saleem U. Ethnobotanical studies from northern areas of Pakistan. Pharmacologyonline. 2009;354:328-54.

135. Gulshan BA, Dasti AA, Hussain S, Atta IM, Amin-Ud-Din M. Indigenous uses of medicinal plants in rural areas of Dera ghazi khan, Punjab, Pakistan. Agric Biol Sci. 2012;7(9):750.

136. Hamayun M. Ethnobotanical studies of some useful shrubs and trees of District Buner, NWFP, Pakistan. Ethnobot Leaflets. 2003;1:12.

137. Pavela R. History, presence and perspective of using plant extracts as commercial botanical insecticides and farm products for protection against insects-a review. Plant Prot Sci. 2016;52:229-41.

138. Jivad N, Bahmani M, Asadi-Samani M. A review of the most important medicinal plants effective on wound healing on ethnobotany evidence of Iran. Der Pharm Lett. 2016;8(2):353-7.

\footnotetext{
Ready to submit your research? Choose BMC and benefit from:

- fast, convenient online submission

- thorough peer review by experienced researchers in your field

- rapid publication on acceptance

- support for research data, including large and complex data types

- gold Open Access which fosters wider collaboration and increased citations

- maximum visibility for your research: over $100 \mathrm{M}$ website views per year
}

At BMC, research is always in progress.

Learn more biomedcentral.com/submissions 